\title{
Systematic study of halide-induced ring opening of 2-substituted aziridinium salts and theoretical rationalization of the reaction pathways
}

\author{
Matthias D'hooghe, ${ }^{[\mathrm{a}]}$ Saron Catak, ${ }^{[\mathrm{b}, \mathrm{c}]}$ Sonja Stankovic, ${ }^{[\mathrm{a}]}$ Michel Waroquier, ${ }^{[\mathrm{b}, \mathrm{c}]}$ Yongeun \\ Kim, ${ }^{[\mathrm{d}]}$ Hyun-Joon Ha, ${ }^{*[\mathrm{~d}]}$ Veronique Van Speybroeck, ${ }^{*[\mathrm{~b}, \mathrm{c}]}$ and Norbert De Kimpe ${ }^{*[\mathrm{a}]}$ \\ ${ }^{[a]}$ Department of Organic Chemistry, Faculty of Bioscience Engineering, Ghent University, \\ Coupure Links 653, B-9000 Ghent, Belgium \\ ${ }^{[b]}$ Center for Molecular Modeling, Ghent University, Technologiepark 903, B-9052 Zwijnaarde, \\ Belgium \\ ${ }^{[c]}$ QCMM-Alliance Ghent-Brussels, Belgium \\ ${ }^{[d]}$ Department of Chemistry and Protein Research Center for Bio-Industry, Hankuk University of \\ Foreign Studies, Yongin, 449-791, Korea
}

\begin{abstract}
The ring opening of 2-alkyl-substituted 1,1-di(arylmethyl)- and 1-methyl-1-(1-phenylethyl)aziridinium salts by fluoride, chloride, bromide and iodide in acetonitrile has been evaluated for the first time in a systematic way, affording regioisomeric mixtures of primary and secondary fluorides, whereas the corresponding secondary $\beta$-chloro, $\beta$-bromo and $\beta$-iodo amines were obtained as the sole reaction products through regiospecific ring opening at the substituted position. Both experimental and computational results revealed a product stability-dictated reaction outcome through thermodynamic control in the chloride, bromide and iodide case, involving rearrangement of the initially formed primary halides to the more stable secondary halides. The ring opening of the same aziridinium salts by fluoride, however, was shown to be mediated by steric interactions (kinetic control), furnishing the corresponding primary $\beta$-fluoro amines as the main reaction products. Only for 2 -acylaziridinium ions, the reaction outcome was shown to be under full substrate control, affording secondary $\beta$-fluoro, $\beta$ chloro, $\beta$-bromo and $\beta$-iodo amines through exclusive attack at the activated $\alpha$-carbonyl carbon atom.
\end{abstract}

\section{Introduction}

The aziridine moiety represents one of the most valuable three-membered ring systems in organic chemistry, ${ }^{[1]}$ and the regiocontrolled ring opening of $C$-substituted aziridines constitutes a powerful approach towards the preparation of a large variety of functionalized nitrogen- 
containing target compounds. In the literature, the ring opening of activated aziridines, i.e. aziridines bearing an electron-withdrawing group at nitrogen, has been studied intensively. ${ }^{[1 \mathrm{~d}]}$ Non-activated aziridines, however, have to be activated prior to ring opening due to the presence of an electron-donating substituent at nitrogen, and have been evaluated to a limited extent up to now. Nevertheless, the reactivity and applications of non-activated aziridines are different and often complementary as compared to activated aziridines and epoxides, providing interesting opportunities for the selective synthesis of a variety of functionalised amines. The most commonly applied methodology in that respect involves the formation of highly electrophilic aziridinium intermediates through $\mathrm{N}$-alkylation, $\mathrm{N}$-acylation, $\mathrm{N}$-protonation or $\mathrm{N}$ complexation with Lewis acids, which then can easily be opened by different types of nucleophiles.

The ring opening of aziridinium salts by halides constitutes a convenient approach towards $\beta$ halo amines, which are generally recognized as useful building blocks in organic chemistry ${ }^{[2]}$ and valuable targets in medicinal chemistry (nitrogen mustards - chemotherapy agents). ${ }^{[3]}$ If 2 -substituted aziridines are used for the synthesis of the corresponding $\beta$-halo amines, the issue of regioselectivity in the ring opening of the intermediate aziridinium salts becomes important, as two regioisomeric $\beta$-halo amines can be obtained. As depicted in Scheme 1, ring opening of aziridinium salts $\mathbf{1}$ can occur at the unsubstituted (path a) or the substituted aziridine carbon atom (path b), leading either to primary halides 2 (path a) or to secondary halides $\mathbf{3}$ (path b).

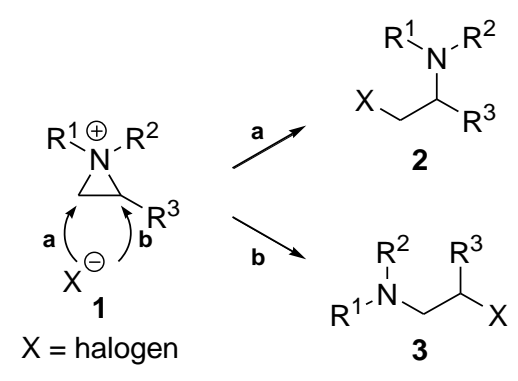

Scheme 1. Regioselectivity in the ring opening of 2-subsitituted aziridinium salts $\mathbf{1}$

In the literature, a number of reports are available on the synthesis of $\beta$-halo amines through ring opening of aziridinium salts by halides. ${ }^{[4]}$ In most cases, 2-vinyl- and 2-arylaziridinium salts have been evaluated, in which the regioselectivity is substrate-dictated due to the presence of a pronounced electrophilic centre at the substituted aziridine carbon atom. The use of 2-alkyl-substituted aziridinium ions has somewhat been neglected in that respect, 
probably because of the potential influence of different parameters such as the type of nucleophile, substrate and solvent on the reaction outcome.

Whereas the issue of regioselectivity has been addressed in a number of literature reports, no systematic study has been performed up to now in which aziridinium substrates are subjected to ring opening by fluoride, chloride, bromide and iodide. In the present paper, two different types of 2-substituted aziridinium salts, i.e. in situ generated and preformed aziridinium ions, have been used as electrophiles for ring opening by fluoride, chloride, bromide and iodide in acetonitrile in a systematic way. In continuation of our interest in the study of ring opening reactions of 2 -substituted aziridinium salts, ${ }^{[5]}$ special attention has been devoted to the regioselectivity of these ring openings with regard to nucleophile- and substrate-dependency, and the observed pathways have been rationalized by detailed computational analysis.

\section{Experimental results and discussion}

In a first approach, the systematic study of halide-induced ring opening of intermediate 2aryloxymethyl-1,1-di(arylmethyl)aziridinium salts was contemplated. As reported before, 2(aryloxymethyl)aziridines $\mathbf{4}$ can be prepared in high yields and purity upon treatment of the corresponding 2-(bromomethyl)aziridines ${ }^{[6]}$ with two equiv of the appropriate potassium phenolate in a DMF/acetone (1/1) solvent system under reflux for 10-20 hours. ${ }^{[7]}$ Subsequent treatment of the latter aziridines $\mathbf{4}$ with one equiv of benzyl bromide in acetonitrile is known to afford secondary bromides $\mathbf{5}$ as the sole reaction products in high yields after reflux for five hours. ${ }^{[7]}$ In order to provide an entry into the corresponding fluorides, chlorides and iodides as well, $\beta$-bromo amines 5 were treated with different halide sources. Thus, both novel $\beta$-chloro amines $\mathbf{6}$ and $\beta$-iodo amines 7 were prepared as the sole reaction products by the use of either 10 equiv of tetraethylammonium chloride or 20 equiv of sodium iodide, respectively, in acetonitrile after reflux for three hours (Scheme 2, Table 1). The formation of the other regioisomers was excluded based on detailed spectroscopic analysis.

The conversion of $\beta$-bromo amines 5 into $\beta$-chloro amines $\mathbf{6}$ using 20 equiv of $\mathrm{NaCl}$ instead of tetraethylammonium chloride in acetonitrile proceeded very sluggishly, as no conversion occurred after heating under reflux for 4 hours and only partial conversion was observed after reflux for 60 hours. On the other hand, the reaction of $\beta$-bromo amines 5 with 10 equiv of tetrabutylammonium iodide in acetonitrile appeared to be less successful as compared to the use of sodium iodide, as only $50 \%$ conversion took place after reflux for 7 hours. If 15 equiv 
of sodium iodide were used instead of 20 equiv, a longer reaction time (5 hours) was required in order to drive the reaction to completion.

When $\beta$-bromo amines 5 were treated with two equiv of tetrabutylammonium fluoride in acetonitrile, however, a mixture of regioisomeric fluorides $\mathbf{8}$ and $\mathbf{9}$ were obtained after reflux for 15 hours (Scheme 2, Table 1). ${ }^{[5]}$ In this case, primary fluorides 8 were formed as the major reaction products, besides minor amounts of secondary fluorides 9 (ratio 8/9 5-6/1). In order to test the reaction outcome as a function of reaction time and temperature, prolonged and elevated reaction times were also evaluated. In particular, heating under reflux for 3 days instead of 15 hours did not affect the isomeric distribution (ratio 8/9: 5-6/1), and the same conclusion was drawn after heating under reflux for 25 hours in DMF. These observations point to the fact that the product distribution between primary and secondary fluorides $\mathbf{8}$ and $\mathbf{9}$ is not under thermodynamic control.

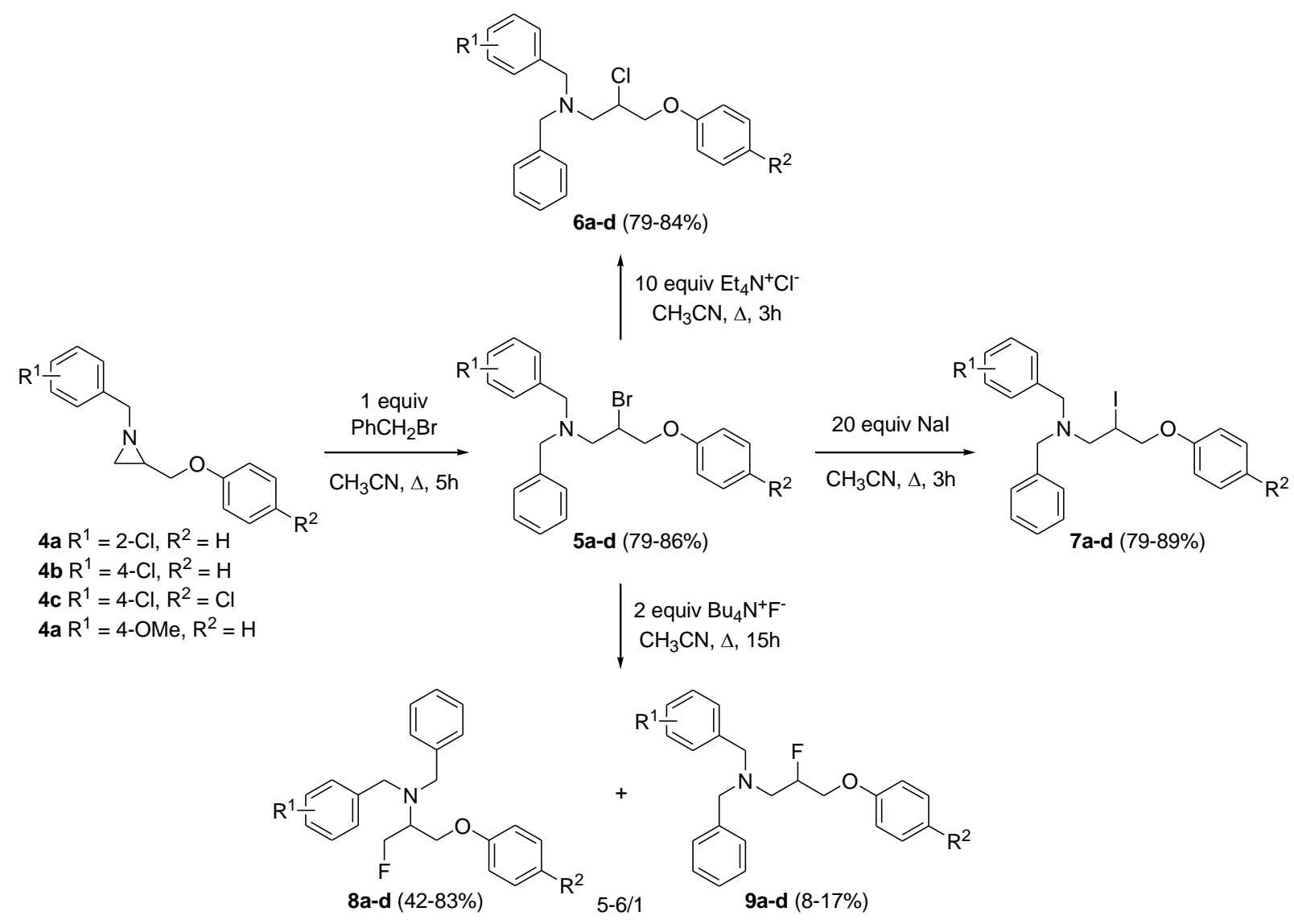

Scheme 2. Synthesis of $\beta$-bromo amines $\mathbf{5}, \beta$-chloro amines $\mathbf{6}, \beta$-iodo amines 7 and $\beta$-fluoro amines 8 and 9. 
Table 1. Synthesis of $\beta$-bromo amines $\mathbf{5}, \beta$-chloro amines $\mathbf{6}, \beta$-iodo amines $\mathbf{7}$ and $\beta$-fluoro amines $\mathbf{8}$ and 9.

\begin{tabular}{ccccccccc}
\hline Entry & $\mathrm{R}^{1}$ & $\mathrm{R}^{2}$ & $\mathbf{5}$ (yield) & $\mathbf{6}$ (yield) & $\mathbf{7}$ (yield) & $\mathbf{8}$ (yield) & $\mathbf{9}$ (yield) & Ratio $^{\mathrm{a}} \mathbf{8 / 9}$ \\
\hline 1 & $2-\mathrm{Cl}$ & $\mathrm{H}$ & $\mathbf{5 a}(71 \%)$ & $\mathbf{6 a}(82 \%)$ & $\mathbf{7 a}(89 \%)$ & $\mathbf{8 a}(54 \%)$ & $\mathbf{9 a}(10 \%)$ & $5 / 1$ \\
2 & $4-\mathrm{Cl}$ & $\mathrm{H}$ & $\mathbf{5 b}(86 \%)$ & $\mathbf{6 b}(79 \%)$ & $\mathbf{7 b}(88 \%)$ & $\mathbf{8 b}(42 \%)$ & $\mathbf{9 b}(8 \%)$ & $5 / 1$ \\
3 & $4-\mathrm{Cl}$ & $\mathrm{Cl}$ & $\mathbf{5 c}(85 \%)$ & $\mathbf{6 c}(83 \%)$ & $\mathbf{7 c}(82 \%)$ & $\mathbf{8 c}(60 \%)$ & $\mathbf{9 c}(10 \%)$ & $6 / 1$ \\
4 & $4-\mathrm{OMe}$ & $\mathrm{H}$ & $\mathbf{5 d}(84 \%)$ & $\mathbf{6 d}(84 \%)$ & $\mathbf{7 d}(79 \%)$ & $\mathbf{8 d}(61 \%)$ & $\mathbf{9 d}(14 \%)$ & $6 / 1$ \\
\hline
\end{tabular}

${ }^{\mathrm{a}}$ Ratio determined by ${ }^{1} \mathrm{H}$ NMR analysis

From a mechanistic point of view, the formation of $\beta$-bromo amines $\mathbf{5}, \beta$-chloro amines $\mathbf{6}$, $\beta$ iodo amines 7 and $\beta$-fluoro amines 8 and $\mathbf{9}$ proceeds through ring opening of the same intermediate aziridinium salts $\mathbf{1 0}$ by different halides (Scheme 3 ).

As observed and investigated before, quaternization and subsequent ring opening of 2(aryloxymethyl)aziridines 4 using benzyl bromide produces $\beta$-bromo amines 12 through regiospecific ring opening of aziridinium salts $\mathbf{1 0}$ at the substituted aziridine carbon atom (X $=\mathrm{Br}$, path $\mathrm{b}$, Scheme 3). ${ }^{[5 \mathrm{~b}, \mathrm{i}, 7]}$ Furthermore, in addition to preliminary findings using other types of substrates, ${ }^{[5 c]}$ the ring opening of aziridinum intermediates $\mathbf{1 0}$ by fluoride afforded a mixture of regioisomers in which primary fluorides $\mathbf{1 1}$ are predominant $(\mathrm{X}=\mathrm{F}$, path a, Scheme 3), pointing to a change in regioselectivity as compared to bromide. In previous theoretical studies, it was demonstrated that product stabilities seem to dictate the outcome of the reaction through thermodynamic control in the bromide case, whereas difference in barriers for the fluoride case were shown to be mainly due to the difference in interaction energies, pointing to the fact that sterics dictate the outcome. ${ }^{[5 i]}$

Apparently, the chloride- ${ }^{[8]}$ and iodide-promoted ring opening of aziridinium ions $\mathbf{1 0}$ is controlled by the same factors as compared to bromide-induced ring opening, involving attack at the substituted position ( $\mathrm{X}=\mathrm{Cl}$ and $\mathrm{I}$, path $\mathrm{b}$, Scheme 3). Thus, it can be concluded that chloride-, bromide- and iodide-promoted ring openings of aziridinium ions $\mathbf{1 0}$ are under thermodynamic control, eventually leading to the more stable secondary halides $\mathbf{1 2}$ as the final reaction products. On the other hand, ring opening by fluoride is kinetically controlled, which can be rationalized considering the poor leaving group capacity of fluoride as compared to the other halides, preventing thermodynamic equilibration. 


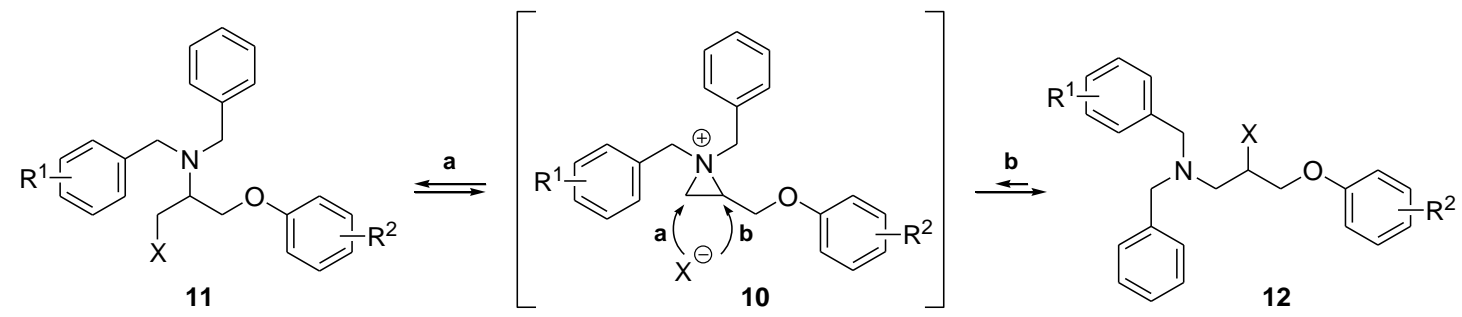

Scheme 3. Regioselectivity in the ring opening of aziridinium salts $\mathbf{1 0}$ by different halides.

In order to provide insight into the potential role of the substrate in the above-described ring opening reactions, the synthesis of another type of aziridinium salts was devised in the second part. In addition to non-isolable aziridinium intermediates 10, stable 1-methylaziridinium triflates 14 were prepared through $N$-methylation of chiral aziridines 13 upon treatment with 1.1 equiv of methyl trifluoromethanesulfonate in acetonitrile for 10 minutes (Scheme 4), and were then evaluated as electrophiles for halide-induced ring opening reactions. Chiral substrates 13a,b were prepared starting from the corresponding commercially available $2(R)$ hydroxymethyl-1-[1(R)-phenylethyl]aziridine according to literature protocols. ${ }^{[5 \mathrm{c}, \mathrm{g}, \mathrm{h}]}$

In the present work, different tetrabutylammonium halides were used as halide sources for the ring opening of aziridinium triflates 14. First, the reaction of 2-(methoxymethyl)aziridinium ions $14 \mathbf{a}\left(\mathrm{R}=\mathrm{CH}_{2} \mathrm{OMe}\right)$ with 1.5 equiv of tetrabutylammonium fluoride, chloride, bromide or iodide in acetonitrile at room temperature for one hour afforded the corresponding $\beta$-halo amines in good yields. Interestingly, the same conclusions were drawn as described above, involving the selective synthesis of secondary bromide 16a, iodide $\mathbf{1 6 b}$ and chloride $\mathbf{1 6 \mathbf { d }}$ as the sole reaction products, besides a regioisomeric mixture of primary and secondary fluoride 15c and 16c (3/1) (Scheme 4, Table 2). These observations further consolidate the nucleophile-dependency of ring opening reactions of 1,1,3-trialkylaziridinium ions by halides, pointing to a chloride-, bromide- and iodide-mediated ring opening under thermodynamic control and a fluoride-induced ring opening under kinetic control.

Nonetheless, the nucleophile-dependency of aziridinium ring opening reactions is overruled by substrate control if an activated aziridine carbon atom is present in the substrate. For example, upon use of 2-(ethoxycarbonyl)aziridinium salts $14 \mathbf{b}\left(\mathrm{R}=\mathrm{CO}_{2} \mathrm{Et}\right)$, only the corresponding secondary halides were obtained through ring opening at the activated $\alpha$ carbonyl atom after reaction with 1.5 equiv of tetrabutylammonium halide in acetonitrile at 
room temperature, and no primary halides were retrieved (Scheme 4, Table 1). Thus, $\alpha$-halo esters 16e-h were formed through regiospecific ring opening of aziridinium salts $\mathbf{1 4 b}$ at the substituted aziridine carbon atom (path b, Scheme 4).
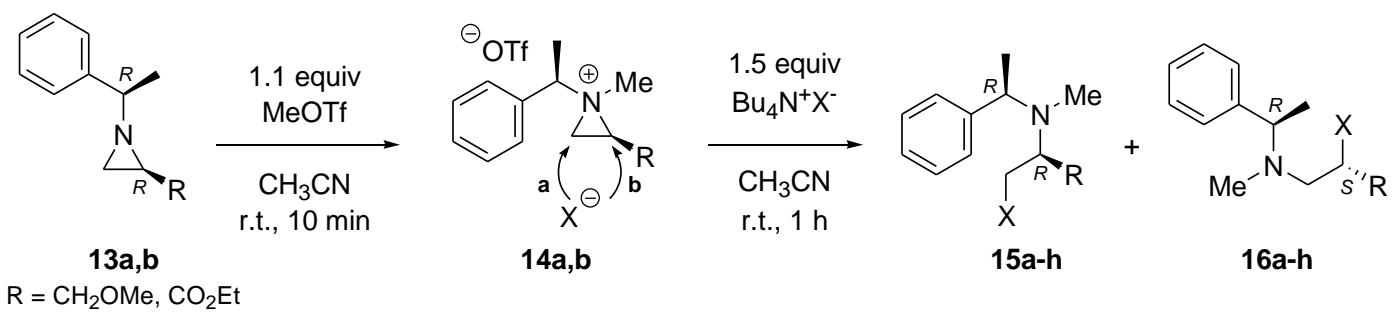

Scheme 4. Ring opening of 1-methylaziridinium triflates 14 by tetrabutylammonium halides.

Table 2. Ring opening of 1-methylaziridinium triflates 14 by tetrabutylammonium halides.

\begin{tabular}{cccccc}
\hline Entry & Substrate & $\mathrm{R}$ & $\mathrm{X}$ & Product & Yield(\%) \\
\hline 1 & $\mathbf{1 4 a}$ & $\mathrm{CH}_{2} \mathrm{OMe}$ & $\mathrm{Br}^{-}$ & $\mathbf{1 6 a}$ & $47 \%$ \\
2 & $\mathbf{1 4 a}$ & $\mathrm{CH}_{2} \mathrm{OMe}$ & $\mathrm{I}^{-}$ & $\mathbf{1 6 b}$ & $52 \%$ \\
3 & $\mathbf{1 4 a}$ & $\mathrm{CH}_{2} \mathrm{OMe}$ & $\mathrm{F}^{-}$ & $\mathbf{1 5 c}+\mathbf{1 6 c}$ & $77 \%(3 / 1)$ \\
4 & $\mathbf{1 4 a}$ & $\mathrm{CH}_{2} \mathrm{OMe}$ & $\mathrm{Cl}^{-}$ & $\mathbf{1 6 d}$ & $73 \%$ \\
5 & $\mathbf{1 4 b}$ & $\mathrm{CO}_{2} \mathrm{Et}$ & $\mathrm{Br}^{-}$ & $\mathbf{1 6}$ & $92 \%^{\mathrm{a}}$ \\
6 & $\mathbf{1 4 b}$ & $\mathrm{CO}_{2} \mathrm{Et}$ & $\mathrm{I}^{-}$ & $\mathbf{1 6 f}$ & $90 \%^{\mathrm{a}}$ \\
7 & $\mathbf{1 4 b}$ & $\mathrm{CO}_{2} \mathrm{Et}$ & $\mathrm{F}^{-}$ & $\mathbf{1 6 g}$ & $71 \%$ \\
8 & $\mathbf{1 4 b}$ & $\mathrm{CO}_{2} \mathrm{Et}$ & $\mathrm{Cl}^{-}$ & $\mathbf{1 6 h}$ & $83 \%$ \\
\hline
\end{tabular}

${ }^{a}$ Compounds decomposed during chromatographic purification

Interestingly, when aziridinium triflate 14a was treated with 1.5 equiv of $\mathrm{NaCl}$ in acetonitrile (20 hours, rt) instead of $\mathrm{Bu}_{4} \mathrm{~N}^{+} \mathrm{Cl}^{-}$, the initial formation of a different reaction product was observed upon chromatographic analysis (TLC), which slowly underwent conversion into secondary $\beta$-chloro amine 16d upon standing at the room temperature. Although purification by column chromatography on silica gel failed, the initially formed reaction product could be identified as 2-amino-3-chloro-1-methoxypropane 15d by ${ }^{1} \mathrm{H}$ NMR analysis. Obviously, the latter primary chloride comprises the kinetically controlled reaction product obtained through ring opening of aziridinium ion $\mathbf{1 4 a}$ at the unsubstituted position (route a, Scheme 4), which then rearranges into the more stable secondary chloride via a thermodynamic equilibrium. The same observation was made through careful analysis of the reaction outcome after treatment of aziridinium triflate 14a with 1.5 equiv of $\mathrm{Me}_{4} \mathrm{~N}^{+} \mathrm{Cl}^{-}$. The product distribution between 
aziridinium ion $14 a$, primary chloride $15 \mathbf{d}$ and secondary chloride $16 \mathbf{d}$ was evaluated by ${ }^{1} \mathrm{H}$ NMR $\left(\mathrm{CDCl}_{3}\right)$, as shown in Figure 1. It should be noted that these findings comprise the first experimental proof for the occurrence of a thermodynamic equilibrium in the halide-induced ring opening of 2-alkyl-substituted aziridinium salts.

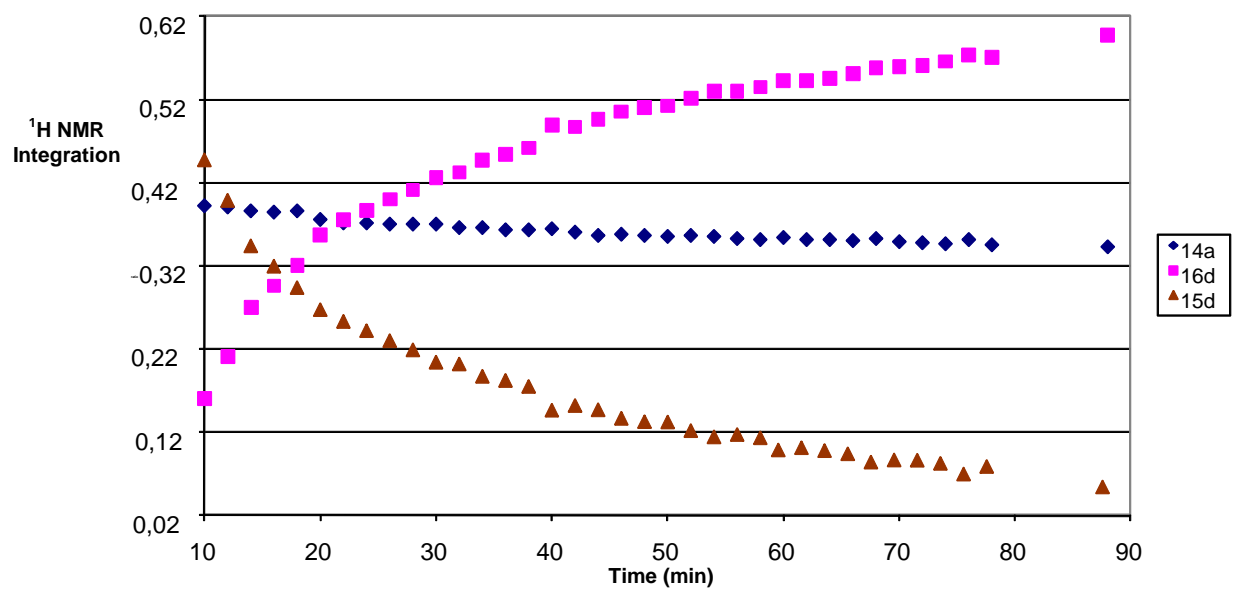

Figure 1. Product distribution between $\mathbf{1 4 a}, \mathbf{1 5 d}$ and $\mathbf{1 6 d}$ as a function of reaction time.

From these experiments, it can be concluded that the ring opening of 2-alkyl-substituted aziridinium salts 17 by chloride, bromide and iodide proceeds under thermodynamic control, where product stabilities dictate the outcome of the reaction. Thus, the initially formed kinetic primary halides $\mathbf{1 8}$ undergo rearrangement into the thermodynamically more stable secondary halides 19 (Scheme 5). Fluoride-mediated ring opening, however, is under kinetic control, where the reaction outcome is only dictated by steric interactions.

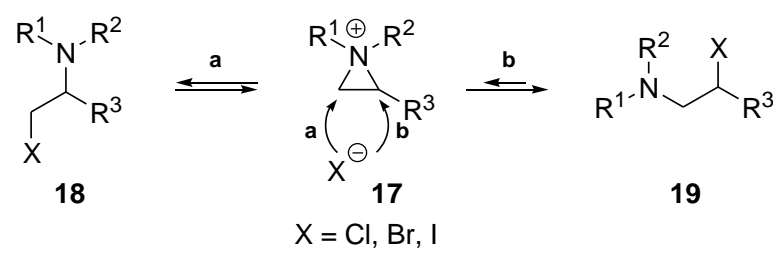

Scheme 5. Thermodynamic control for chloride-, bromide- and iodide-induced ring opening of aziridinium salts. 


\section{Theoretical rationalization}

Computational studies have been previously performed on fluoride- and bromide-mediated ring opening of various $N, N$-dibenzylaziridinium ions, ${ }^{[5 \mathrm{a}, \mathrm{d}, \mathrm{i}]}$ however, a systematic evaluation is necessary for the rationalization of the observed trend in the halide series. In order to elucidate the factors causing the differences in regioselectivity, a thorough computational analysis was performed on the halide-mediated ring opening of 14a. Iodide-induced ring opening reactions have been excluded from this study, since they show similar experimental regioselectivity to bromide, and the main aim of this computational study is to elucidate the factors causing the difference in experimental regioselectivities.

\section{Computational Methodology}

Reaction pathways for the nucleophilic attack of halides on aziridinium ion 14a were obtained at the B3LYP/6-31++G(d,p) level of theory. ${ }^{[9,10]}$ Stationary points were characterized as minima or first-order saddle points via frequency calculations. Intrinsic reaction coordinate $(\text { IRC })^{[11]}$ calculations followed by full geometry optimizations were used to verify reactant complexes (ion-dipole complex) and products reached by each transition state. Energies were further refined by MPW1B95 ${ }^{[12]}$ single-point calculations, since this method was recently shown to successfully reproduce SCS-MP2 ${ }^{[13]}$ results in the ring opening of aziridines with benzyl bromide. ${ }^{[5 i]}$ The effect of a polar environment has been taken into account by use of the self-consistent reaction field (SCRF) theory ${ }^{[14]}$ Solvation free energies in acetonitrile $(\varepsilon=$ $35.688)$ were obtained utilizing the conductor-like polarizable continuum (C-PCM) model. ${ }^{[15]}$ All DFT calculations were carried out with the Gaussian 03 program package. ${ }^{[16]}$

Explicit acetonitrile molecules were used to solvate halide ions, since gas-phase calculations, in which bare halide ions attack the electrophilic aziridinium ion, were previous shown to give unrealistic results and were incapable of representing the real system at hand. ${ }^{[4 i]}$ Accordingly, previous modeling studies on the bromide-induced ring opening of aziridinium ions have effectively made use of explicit solvent molecules, as this was previously shown to be vital in reproducing realistic potential energy surfaces. ${ }^{[5 \mathrm{~d}, \mathrm{i}]}$ The use of discrete solvent molecules to stabilize chemically active species in reactions is a well-established methodology, ${ }^{[17]}$ and was followed by the present authors in a recent study, which successfully pointed to the correct regioselective outcome in azirdinium ring opening reactions. ${ }^{[4 i]}$ However, this approach only accounts for short-range interactions, such as ion-dipole complexes and does not take into 
account potential long-range interactions with solvent molecules, which are likely to be significant when anionic nucleophiles are involved, such as the case herein. In light of this, the supermolecule was also placed in a dielectric continuum, ${ }^{[18]}$ leading to a mixed implicit/explicit solvent model. ${ }^{[19]}$ A recent comparative study has shown that mixed models should be used with caution as they may give unreliable results. ${ }^{[20]}$ Nonetheless, the mixed implicit/explicit solvent model has been employed in addition to the supermolecule approach for comparative purposes.

\section{Nucleophilic Ring Opening Mechanisms}

Nucleophilic ring opening can occur via attack at the unhindered (pathway a) or hindered (pathway b) aziridine carbons (Scheme 1). Both reaction pathways were modeled for fluoride, chloride and bromide. Consequent comparison of reaction barriers and relative stabilities of products will help understand the factors controlling regioselectivity. Halide-induced ring openings were modeled with the use of explicit solvent molecules; three acetonitrile molecules have been used to solvate the fluoride, chloride and bromide ions that attack the aziridinium ring, as this was previously shown to be adequate for the solvation of the halide ion. ${ }^{[5 i]}$

Transition state geometries for the $S_{N} 2$ attack of halides on both aziridine carbons of 14a are illustrated in Figure 2. Acetonitrile molecules stabilize the halide ions through charge-dipole interactions; typical $\mathrm{X} \bullet \bullet \mathrm{H}_{3} \mathrm{C}-\mathrm{CN}$ distances for fluoride, chloride and bromide are 2.0, 2.6 and 2.75 , respectively. Critical distances, indicating ring opening within the aziridine as well as nucleophile-to-aziridine attack, are considerably different in both pathways for all halides.
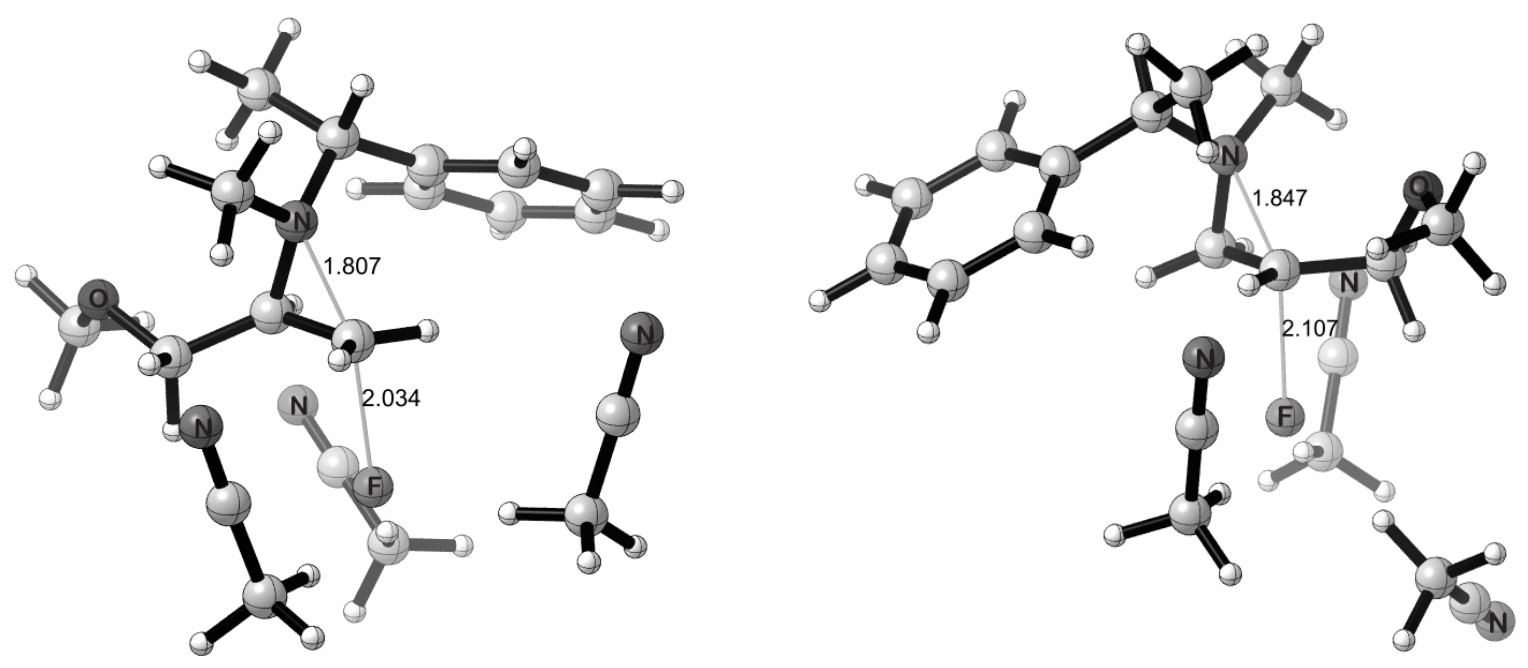
F-TS-a

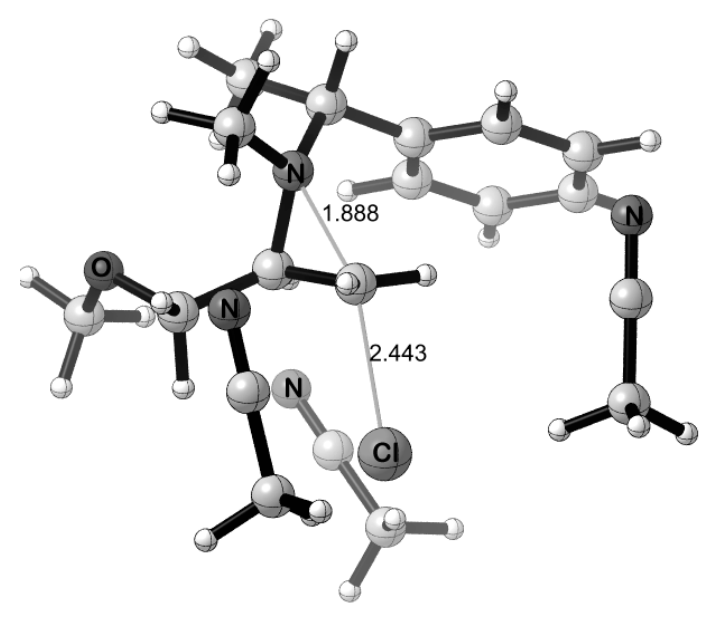

Cl-TS-a

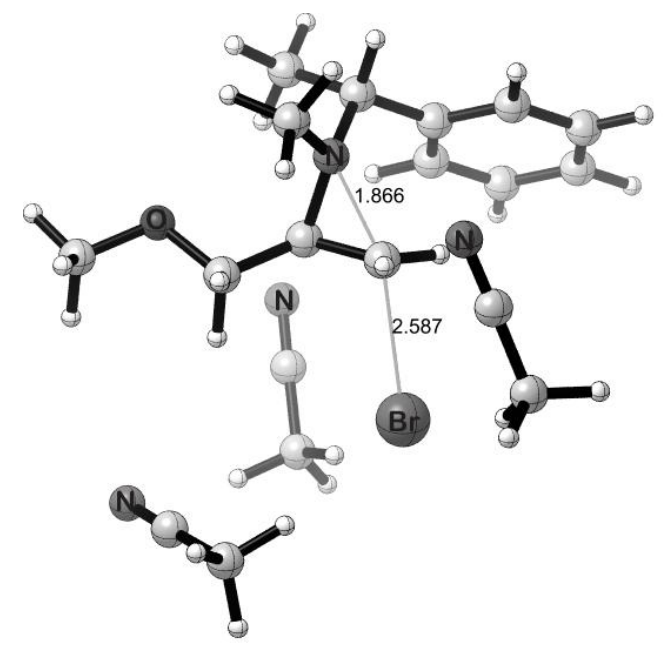

Br-TS-a
F-TS-b

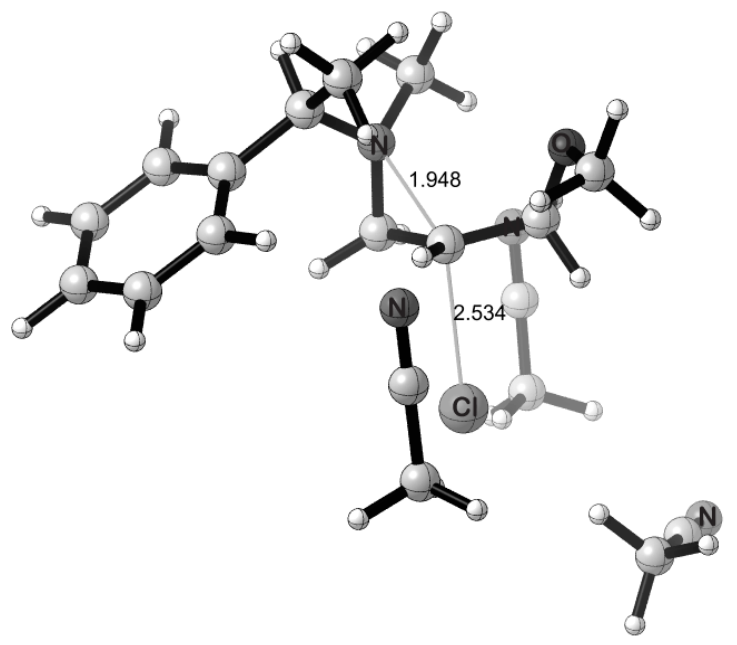

Cl-TS-b

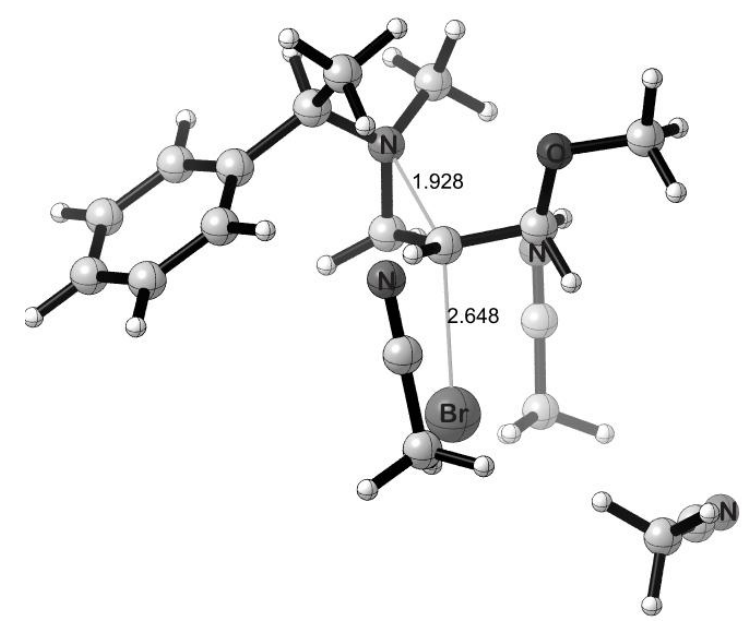

Br-TS-b

Figure 2. Transition state geometries optimized at the B3LYP/6-31++G(d,p) level of theory for halide-induced nucleophilic ring opening of aziridinium ion 14a through pathways $a$ and $b$. Some critical distances are given in units of $\AA$. 
Relative energetics show that the barrier for pathway $a$ is systematically lower than that for pathway $b$ for all three halides studied, i.e. the kinetically favored pathway is always the unhindered one as sterics would suggest. Differences in activation energies among pathways $a$ (unhindered) and $b$ (hindered) are shown in Table 3. On the other hand, differences in reaction energies show that pathway $b$ leads to the thermodynamically more stable product in all three cases. As mentioned earlier, the supermolecule (Figure 3) has additionally been embedded in a dielectric continuum in order to take into account long range interactions with the bulk solvent. This mixed implicit/explicit solvent approach is shown to have the same trend as the discrete continuum model (supermolecule), which is solely solvated by explicit solvent molecules.

Table 3: Differences in Electronic $\left(\Delta \Delta E^{\dagger}\right)$ and Free $\left(\Delta \Delta G^{\dagger}\right)$ Energies of Activation and Electronic $\left(\Delta \Delta E^{r x n}\right)$ and Free $\left(\Delta \Delta G^{r x n}\right)$ Energies of Reaction for Halide-Induced Nucleophilic Ring Opening of 14a via Pathways $a$ (unhindered) and $b$ (hindered). ${ }^{[\mathrm{a}, \mathrm{b}]}$

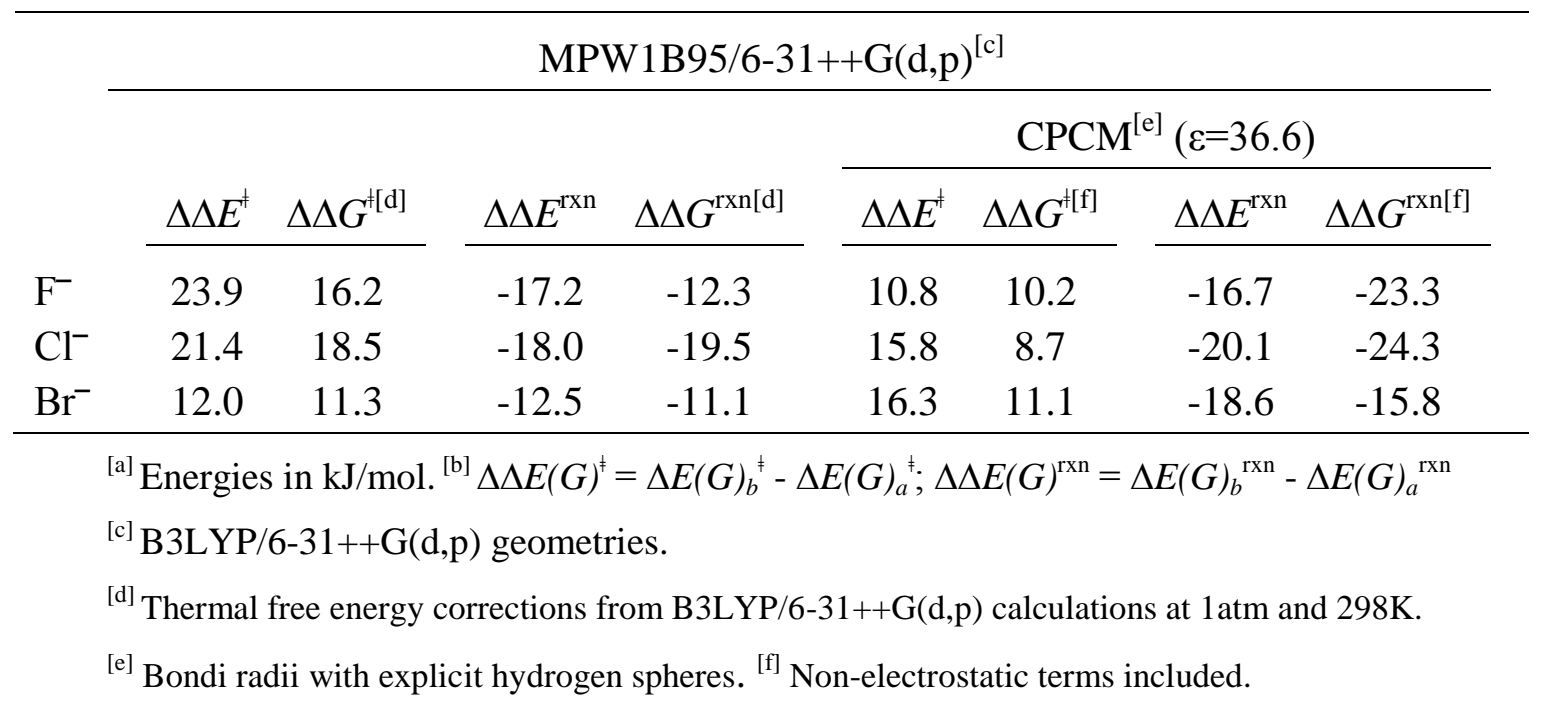


Potential energy surfaces (PES) for the halide-induced nucleophilic ring opening of 14a via pathways $a$ (unhindered) and $b$ (hindered) for all three halides are illustrated in Figure 3. There is a substantial barrier difference between the two pathways for fluoride attack, favoring the unhindered route (pathway $a$ ), which also leads to the experimentally observed major product, F-P-a (15c). Although F-P-b (16c) is shown to be thermodynamically more stable (Figure 3), since fluoride is a rather poor leaving group, thermodynamic equilibration requires overcoming a back reaction barrier of approximately $130 \mathrm{~kJ} / \mathrm{mol}$. This explains the mixture of both products (15c and 16c) observed for the fluoride-mediated ring opening of 14a. For chloride, reaction barriers for both pathways are approximately $15 \mathrm{~kJ} / \mathrm{mol}$ lower than the fluoride case, consistent with nucleophile strength; the softer the nucleophile the lower the barrier for attack. Reaction energies are also significantly different; this is in line with relative leaving group abilities. For chloride, Cl-P-b (16d) is more stable than Cl-P-a (15d) by 20 $\mathrm{kJ} / \mathrm{mol}$, whereas Cl-TS-a is more feasible than Cl-TS-b by the same amount. Once again the kinetic route suggests pathway a, leading to $15 \mathbf{d}(\mathrm{Cl}-\mathrm{P}-\mathrm{a})$, however back reaction barriers are reasonably low (approximately $75 \mathrm{~kJ} / \mathrm{mol}$ ) and thermodynamic equilibration is feasible, leading to the energetically more stable final product Cl-P-b (16d). This explains the initial observation of $\mathbf{1 5 d}$ during ring-opening with chloride. For bromide, the difference between Br-TS-a and Br-TS-b is smaller when compared to chloride. Product stabilities favor pathway $b$ and back reaction barriers are quite low, easily allowing equilibration to yield the more stable product, Br-P-b (16a) (Table 3). Since Br-TS-b is lower than Cl-TS-b, it is likely that equilibration takes place much faster for bromide and the kinetic product $\mathrm{Br}-\mathrm{P}-\mathrm{a}$ (15a) is, therefore, not experimentally observed.

The overall picture for halide-induced ring opening shows that the unhindered route (pathway a) is always kinetically preferred, however, the hindered route leads to the thermodynamic product. The eventual outcome depends on the softness and leaving group ability of the nucleophile (halide). If the nucleophile is a good leaving group (soft nucleophile, bromide), back reaction barriers are sufficiently low to allow equilibration and the thermodynamic product will prevail. If the nucleophile is a poor leaving group (hard nucleophile, fluoride), the back reaction is unlikely and the kinetic route will dictate the reaction outcome. In the case of bromide, equilibration is so rapid that the initial formation of the kinetic product $(\mathrm{Br}-$ $\mathrm{P}$-a) is not observed. For the chloride case, however, equilibration is slower; therefore the kinetic product (15d) is initially observed during the reaction. Theoretical results are in 
perfect agreement with experimental findings, also pointing to the well-known trend in nucleophile strength and leaving group ability throughout the halide series.

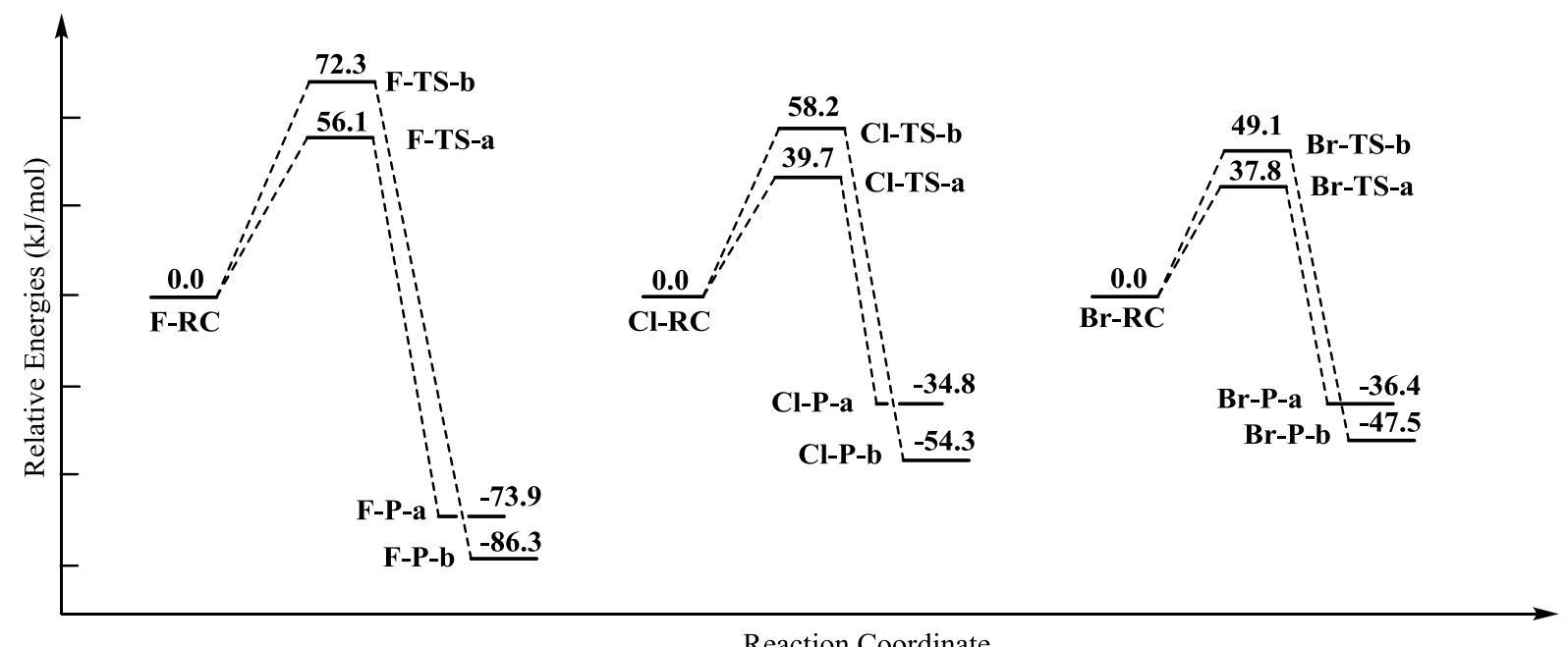

Figure 3. Free Energy Surfaces (FES) for the halide-induced nucleophilic ring opening of 14a via pathways $a$ (unhindered) and $b$ (hindered). (MPW1B95/6-31++G(d,p)//B3LYP/6$31++\mathrm{G}(\mathrm{d}, \mathrm{p}))$. Relative energies are given in $\mathrm{kJ} / \mathrm{mol}$.

\section{Distortion/Interaction Model}

Efforts to rationalize the experimentally observed reaction outcomes have also led to comparative analysis of the transition state structures via the distortion/interaction model. To further verify the relationship between the structural distinctions and the difference in relative free energies of the transition states the activation strain model of chemical reactivity by Bickelhaupt, ${ }^{[21]}$ also known as the distortion/interaction model by Houk, ${ }^{[22]}$ was employed.

$$
\Delta E^{\dagger}=\Delta E_{\mathrm{dist}}^{\dagger}+\Delta E_{\mathrm{int}}^{\dagger}
$$

The distortion/interaction model dissects the activation energy $\left(\Delta E^{\dagger}\right)$ into distortion energy ( $\Delta E_{\text {dist }}^{\ddagger}$, and interaction energy $\left(\Delta E_{\text {int }}^{\dagger}\right.$ ) between distorted fragments, where the former is associated with the strain caused by deforming the individual reactants, the latter is the favorable interaction between the deformed reactants. Fragment distortion and interaction energies (MPW1B95/6-31++G(d,p)) are given in Table 4. 
Table 4. Differences in Reaction Barriers $\left(\Delta \Delta E^{\dagger}\right)$, Distortion $\left(\Delta \Delta E_{\text {dist }}^{\ddagger}\right)$ and Interaction Energies $\left(\Delta \Delta E_{\text {int }}^{\ddagger}\right)(($ MPW1B95/6-31++G(d,p), kJ/mol) between Pathways $a$ and $b$ for the Hydride and Halide-Induced Nucleophilic Ring Opening of $\mathbf{1 4 a} .^{\text {a,b }}$

\begin{tabular}{llll}
\hline & $\Delta \Delta E^{\dagger}$ & $\Delta \Delta E_{\text {dist }}^{\dagger}$ & $\Delta \Delta E_{\text {int }}^{\dagger}$ \\
\cline { 2 - 4 } $\mathrm{F}^{-}$ & 23.9 & 7.5 & 16.4 \\
$\mathrm{Cl}^{-}$ & 21.4 & 9.5 & 11.9 \\
$\mathrm{Br}^{-}$ & 12.0 & 13.0 & -1.1 \\
\hline${ }^{\mathrm{a}} \Delta \Delta E^{\dagger}=\Delta E_{b}^{\dagger}-\Delta E_{a}^{\ddagger}$ \\
${ }^{\mathrm{b}} \mathrm{B} 3 \mathrm{LYP} / 6-31++\mathrm{G}(\mathrm{d}, \mathrm{p})$ geometries.
\end{tabular}

Distortion energy is shown to increase while going from fluoride to bromide. The penalty for distorting the aziridinium ring is larger as the nucleophile gets larger; this is also reflected in the difference in elongation in the aziridinium ring (Figure 2) and is an indication of the difference in progression along the reaction coordinate; the transition state is more and more product-like going down the halide series. There is a substantial difference in $\Delta \Delta E_{\text {dist }}^{\ddagger}$ among the halides studied, even though the substrate is the same for all three cases. This indicates that transition states occur at different positions along the reaction coordinate, which in turn also explains the stronger TS interaction $\Delta \Delta E_{\text {int }}^{\dagger}$, as suggested earlier by Bickelhaupt. ${ }^{[23]}$

Distortion/interaction calculations have revealed that for bromide, the main contribution to the difference in activation barriers comes from the strain caused by the deforming the reactant, while no difference in orbital interactions among competing pathways was present. However, for fluoride and chloride, the difference in energy barriers leading to the two competing pathways is significantly affected by the difference in interaction energies between the two transition states, indicating that fluoride and chloride ions are much more influenced by the sterics around the aziridine carbon under attack. This is certainly not the case for bromide, which is considerably further away from the aziridinium moiety in the transition state (bromide aziridine carbon distances in the transition state are approximately $2.6 \AA$, Figure 2), suggesting that bromide is not affected by the difference in sterics.

\section{Conclusions}

In summary, the ring opening of both non-isolable and stable 2-alkyl-substituted aziridinium salts by fluoride, chloride, bromide and iodide was studied for the first time in a systematic 
way, pointing to an inherent difference in reactivity between fluoride on the one hand and chloride, bromide and iodide on the other. Both experimental and computational evidence was provided for the fact that product stabilities dictate the reaction outcome through thermodynamic control in the chloride, bromide and iodide case, involving rearrangement of the initially formed primary halides to the more stable secondary halides via a thermodynamic equilibrium. The ring opening of the same aziridinium salts by fluoride, however, was shown to be mediated by steric interactions (kinetic control), as the difference in barriers were mainly due to the difference in interaction energies. For 2-acylaziridinium ions, the reaction outcome was shown to be under full substrate control, affording secondary $\beta$-halo amines through attack at the activated $\alpha$-carbonyl carbon atom regardless of the nature of the halide.

\section{Experimental part}

\section{Synthesis of 1-arylmethyl-2-(aryloxymethyl)aziridines $4^{[7]}$}

As a representative example, the synthesis of 1-[(4-methoxyphenyl)methyl]-2(phenoxymethyl)aziridine $\mathbf{4 d}$ is described here. 2-Bromomethyl-1-[(4methoxyphenyl)methyl]aziridine ${ }^{[6]}(1.28 \mathrm{~g}, 5 \mathrm{mmol})$ was added to a mixture of phenol (1.03 $\mathrm{g}, 2.2$ equiv) and $\mathrm{K}_{2} \mathrm{CO}_{3}$ (3.45 g, 5 equiv) in a solvent mixture containing acetone and DMF (50 $\mathrm{mL}, 1 / 1$ on volumetric basis), and the resulting mixture was heated under reflux for $15 \mathrm{~h}$. Afterwards, the reaction mixture was poured into brine $(50 \mathrm{~mL})$ and extracted with $\mathrm{Et}_{2} \mathrm{O}(3 \mathrm{x}$ $50 \mathrm{~mL})$. Drying $\left(\mathrm{MgSO}_{4}\right)$, filtration of the drying agent and evaporation of the solvent afforded 1-[(4-methoxyphenyl)methyl]-2-(phenoxymethyl)aziridine 4d, which was purified by means of column chromatography on silica gel (hexane/EtOAc 4/1), (87\% yield, $1.17 \mathrm{~g}$ ) in order to obtain an analytically pure sample.

\section{1-[(4-Chlorophenyl)methyl]-2-(phenoxymethyl)aziridine 4b}

Yield $85 \%$, yellow liquid. $\mathrm{R}_{\mathrm{f}} 0.28$ (hexane/EtOAc 4/1). ${ }^{1} \mathrm{H} \mathrm{NMR}\left(300 \mathrm{MHz}, \mathrm{CDCl}_{3}\right.$ ): $\delta 1.55$ $(1 \mathrm{H}, \mathrm{d}, \mathrm{J}=6.6 \mathrm{~Hz}) ; 1.85(1 \mathrm{H}, \mathrm{d}, \mathrm{J}=3.3 \mathrm{~Hz}) ; 1.94-2.03(1 \mathrm{H}, \mathrm{m}) ; 3.43$ and $3.49(2 \mathrm{H}, 2 \mathrm{x} \mathrm{d}, \mathrm{J}=$ $13.8 \mathrm{~Hz}) ; 3.89$ and $3.99(2 \mathrm{H}, 2 \mathrm{x} \mathrm{d} \mathrm{x} \mathrm{d}, \mathrm{J}=10.3$, 6.3, 5.0 Hz); 6.86-6.96 and 7.22-7.33 (3H and $6 \mathrm{H}, 2 \mathrm{x} \mathrm{m}) .{ }^{13} \mathrm{C} \mathrm{NMR}\left(75 \mathrm{MHz}, \mathrm{CDCl}_{3}\right): \delta 31.8,38.0,63.5,70.0,114.6,120.9,128.5$, 129.3, 129.4, 132.8, 137.4, 158.6. IR (neat): $v_{\max }=2921,1599,1491,1240,1086,1034,1015$, 805, 752, $691 \mathrm{~cm}^{-1}$. MS (70 eV): $\mathrm{m} / z(\%): 274 / 6\left(\mathrm{M}^{+}+1,100\right)$. Anal. Calcd for $\mathrm{C}_{16} \mathrm{H}_{16} \mathrm{ClNO}$ : C 70.20, H 5.89, N 5.12. Found: C 70.31, H 6.04, N 5.21. 


\section{2-[(4-Chlorophenoxy)methyl]-1-[(4-Chlorophenyl)methyl]aziridine 4c}

Yield $82 \%$, yellow liquid. $\mathrm{R}_{\mathrm{f}} 0.10$ (hexane/EtOAc 4/1). ${ }^{1} \mathrm{H}$ NMR (300 MHz, $\mathrm{CDCl}_{3}$ ): $\delta 1.55$ $(1 \mathrm{H}, \mathrm{d}, \mathrm{J}=6.6 \mathrm{~Hz}) ; 1.84(1 \mathrm{H}, \mathrm{d}, \mathrm{J}=3.3 \mathrm{~Hz}) ; 1.91-1.98(1 \mathrm{H}, \mathrm{m}) ; 3.42$ and $3.48(2 \mathrm{H}, 2 \mathrm{x} \mathrm{d}, \mathrm{J}=$ $13.2 \mathrm{~Hz}$ ); 3.83 and 3.99 (2H, $2 \mathrm{x} \mathrm{d} \mathrm{x} \mathrm{d,} \mathrm{J} \mathrm{=} \mathrm{10.4,} \mathrm{6.6,} \mathrm{4.4} \mathrm{Hz);} \mathrm{6.77-6.80,} \mathrm{7.18-7.21} \mathrm{and} \mathrm{7.27-}$ $7.32(2 \mathrm{H}, 2 \mathrm{H}$ and $4 \mathrm{H}, 3 \mathrm{x} \mathrm{m}) .{ }^{13} \mathrm{C}$ NMR $\left(75 \mathrm{MHz} \mathrm{CDCl}_{3}\right): \delta 31.7,37.9,63.5,70.4,115.9$, 125.8, 128.5, 129.29, 129.34, 133.0, 137.3, 157.3. IR (neat): $v_{\max }=2986,2923,2830,1596$, 1489, 1284, 1240, 1171, 1089, 1015, 822, 806, $668 \mathrm{~cm}^{-1}$. MS (70 eV): $\mathrm{m} / z(\%): 308 / 10 / 12$ $\left(\mathrm{M}^{+}+1,100\right)$. Anal. Calcd for $\mathrm{C}_{16} \mathrm{H}_{15} \mathrm{Cl}_{2} \mathrm{NO}$ : C 62.35, H 4.91, N 4.54. Found: $\mathrm{C} 62.42, \mathrm{H}$ $5.23, \mathrm{~N} 4.45$.

\section{1-[(4-Methoxyphenyl)methyl]-2-(phenoxymethyl)aziridine 4d}

Yield $87 \%$, light yellow crystals. $\mathrm{R}_{\mathrm{f}} 0.11$ (hexane/EtOAc 4/1). ${ }^{1} \mathrm{H}$ NMR $\left(300 \mathrm{MHz}, \mathrm{CDCl}_{3}\right): \delta$ $1.52(1 \mathrm{H}, \mathrm{d}, \mathrm{J}=6.6 \mathrm{~Hz}) ; 1.79(1 \mathrm{H}, \mathrm{d}, \mathrm{J}=3.3 \mathrm{~Hz}) ; 1.86-1.97(1 \mathrm{H}, \mathrm{m}) ; 3.37$ and $3.44(2 \mathrm{H}, 2 \mathrm{x}$ $\mathrm{d}, \mathrm{J}=13.2 \mathrm{~Hz}) ; 3.76(3 \mathrm{H}, \mathrm{s}) ; 3.91(2 \mathrm{H}, \mathrm{d}, \mathrm{J}=5.5 \mathrm{~Hz}) ; 6.81-6.93$ and 7.19-7.28 (5H and 4H, 2 x m). ${ }^{13} \mathrm{C} \mathrm{NMR}\left(75 \mathrm{MHz}, \mathrm{CDCl}_{3}\right): \delta 31.8,37.8,55.2,63.6,70.1,113.8,114.6,120.8,129.3$, 129.4, 130.0, 158.7, 158.8. IR (neat): $v_{\max }=2933,2836,1609,1511,1457,1243,1173,1030$, 1018, 809, $760 \mathrm{~cm}^{-1}$. MS (70 eV): $\mathrm{m} / z(\%): 270\left(\mathrm{M}^{+}+1,100\right)$. Anal. Calcd for $\mathrm{C}_{17} \mathrm{H}_{19} \mathrm{NO}_{2}: \mathrm{C}$ 75.81, H 7.11, N 5.20. Found: C 75.67, H 7.27, N 5.08.

\section{Synthesis of $N$-(2-bromo-3-aryloxypropyl)amines 5}

As a representative example, the synthesis of $N$-benzyl- $N$-(4-chlorobenzyl)- $N$-(2-bromo-3phenoxypropyl)amine $\mathbf{5 b}$ is described here. To a solution of 1-[(4-chlorophenyl)methyl]-2(phenoxymethyl)aziridine $4 \mathbf{b}(2.73 \mathrm{~g}, 10 \mathrm{mmol})$ in acetonitrile $(50 \mathrm{~mL})$ was added benzyl bromide ( $1.71 \mathrm{~g}, 1$ equiv) at room temperature under stirring, and the resulting mixture was heated under reflux for $5 \mathrm{~h}$. Afterwards, the reaction mixture was poured into water $(50 \mathrm{~mL})$ and extracted with $\mathrm{Et}_{2} \mathrm{O}(3 \times 50 \mathrm{~mL})$. Drying $\left(\mathrm{MgSO}_{4}\right)$, filtration of the drying agent and evaporation of the solvent afforded $N$-benzyl- $N$-(4-chlorobenzyl)- $N$-(2-bromo-3phenoxypropyl)amine $\mathbf{5 b}$, which was purified by means of column chromatography on silica gel (hexane/EtOAc 1/1), (86\% yield, $3.83 \mathrm{~g}$ ) in order to obtain an analytically pure sample.

\section{$N$-Benzyl- $N$-(4-chlorobenzyl)- $N$-(2-bromo-3-phenoxypropyl)amine 5 b}

Yield $86 \%$, colourless oil. $\mathrm{R}_{\mathrm{f}} 0.76$ (hexane/EtOAc 1/1). ${ }^{1} \mathrm{H}$ NMR (300 MHz, $\mathrm{CDCl}_{3}$ ): $\delta 2.91$ and 3.10 (2H, 2 x d x d, J = 13.8, 7.2, 5.5 Hz); 3.53-3.71 (4H, m); 4.07-4.23 (3H, m); 6.776.80, 6.94-6.99 and 7.22-7.36 $(2 \mathrm{H}, 1 \mathrm{H}$ and $11 \mathrm{H}, 3 \mathrm{x} \mathrm{m}) .{ }^{13} \mathrm{C} \mathrm{NMR}\left(75 \mathrm{MHz}, \mathrm{CDCl}_{3}\right): \delta 48.9$, 
57.8, 58.5, 59.2, 70.0, 114.6, 121.2, 127.4, 128.4, 128.5, 129.0, 129.5, 130.3, 132.9, 137.3, 138.5, 158.1. IR (neat): $v_{\max }=2925,2826,1736,1598,1587,1491,1453,1240,1088,801$, 752, $692 \mathrm{~cm}^{-1}$. MS (70 eV): $\mathrm{m} / \mathrm{z}(\%): 364 / 6(100) ; 444 / 6 / 8\left(\mathrm{M}^{+}+1,15\right)$. Anal. Calcd for $\mathrm{C}_{23} \mathrm{H}_{23}$ BrClNO: C 62.11, H 5.21, N 3.15. Found: C 62.29, H 5.41, N 3.04.

\section{$N$-Benzyl- $N$-(4-chlorobenzyl)- $N$-[2-bromo-3-(4-chlorophenoxy)propyl]amine 5c}

Yield $85 \%$, colourless oil. $\mathrm{R}_{\mathrm{f}} 0.74$ (hexane/EtOAc 1/1). ${ }^{1} \mathrm{H}$ NMR (300 MHz, $\mathrm{CDCl}_{3}$ ): $\delta 2.90$ and 3.08 (2H, 2 x d x d, J = 13.8, 7.4, 5.8 Hz); 3.52-3.72 (4H, m); 4.02-4.14 (3H, m); 6.676.71 and $7.20-7.38(2 \mathrm{H}$ and $11 \mathrm{H}, 2 \mathrm{x} \mathrm{m}) .{ }^{13} \mathrm{C} \mathrm{NMR}\left(75 \mathrm{MHz}, \mathrm{CDCl}_{3}\right): \delta 48.5,57.7,58.6$, $59.4,70.2$, 115.9, 126.2, 127.4, 128.45, 128.53, 129.0, 129.4, 130.3, 133.0, 137.3, 138.5, 156.8. IR (neat): $v_{\max }=2920,2826,1596,1490,1453,1240,1090,821,801,740,697 \mathrm{~cm}^{-1}$. MS (70 eV): $m / z(\%): 398 / 400 / 402\left(\mathrm{M}^{+}+1,100\right)$. Anal. Calcd for $\mathrm{C}_{23} \mathrm{H}_{22} \mathrm{BrCl}_{2} \mathrm{NO}$ : C 57.64, H 4.63, N 2.92. Found: C 57.79, H 4.95, N 2.81.

\section{$N$-Benzyl- $N$-(4-methoxybenzyl)- $N$-(2-bromo-3-phenoxypropyl)amine 5d}

Yield $79 \%$, colourless oil. $\mathrm{R}_{\mathrm{f}} 0.76$ (hexane/EtOAc 1/1). ${ }^{1} \mathrm{H} \mathrm{NMR}\left(300 \mathrm{MHz}, \mathrm{CDCl}_{3}\right): \delta 2.91$ and $3.08(2 \mathrm{H}, 2 \mathrm{x} \mathrm{d} \mathrm{x} \mathrm{d}, \mathrm{J}=13.8,8.3,5.4 \mathrm{~Hz}) ; 3.49-3.74(4 \mathrm{H}, \mathrm{m}) ; 3.77(3 \mathrm{H}, \mathrm{s}) ; 4.01-4.24(3 \mathrm{H}$, $\mathrm{m})$; 6.78-6.83, 6.92-6.97 and 7.15-7.39 (4H, $1 \mathrm{H}$ and 9H, $3 \mathrm{x} \mathrm{m}) .{ }^{13} \mathrm{C} \mathrm{NMR}\left(75 \mathrm{MHz}, \mathrm{CDCl}_{3}\right)$ : $\delta 49.3,55.2,57.8,58.6,59.3,70.2,113.7,114.7,121.1,127.2,128.3,129.0,129.4,130.2$, 130.8, 138.9, 158.3, 158.9. IR (neat): $v_{\max }=2932,2833,1599,1509,1495,1453,1241,1172$, 1034, 813, 752, $691 \mathrm{~cm}^{-1}$. MS (70 eV): $m / z(\%): 360(100) ; 440 / 2\left(\mathrm{M}^{+}+1,30\right)$. Anal. Calcd for $\mathrm{C}_{24} \mathrm{H}_{26} \mathrm{BrNO}_{2}$ : C 65.46, H 5.95, N 3.18. Found: C 65.62, H 6.13, N 3.14.

\section{Synthesis of $N$-(2-chloro-3-aryloxypropyl)amines 6}

As a representative example, the synthesis of $N$-benzyl- $N$-(4-methoxybenzyl)- $N$-(2-chloro-3phenoxypropyl)amine $\mathbf{6 d}$ is described here. To a solution of $N$-benzyl- $N$-(4-methoxybenzyl)$N$-(2-bromo-3-phenoxypropyl)amine 5d (0.44 g, $1 \mathrm{mmol})$ in acetonitrile $(20 \mathrm{~mL})$ was added tetraethylammonium chloride (1.66 g, 10 equiv) at room temperature under stirring, and the resulting mixture was heated under reflux for $3 \mathrm{~h}$. Afterwards, the reaction mixture was poured into water $(50 \mathrm{~mL})$ and extracted with $\mathrm{Et}_{2} \mathrm{O}(3 \times 50 \mathrm{~mL})$. Drying $\left(\mathrm{MgSO}_{4}\right)$, filtration of the drying agent and evaporation of the solvent afforded $N$-benzyl- $N$-(4-methoxybenzyl)$N$-(2-chloro-3-phenoxypropyl)amine 6d, which was purified by means of column chromatography on silica gel (hexane/EtOAc 1/1), (84\% yield, $0.33 \mathrm{~g}$ ) in order to obtain an analytically pure sample. 


\section{$N$-Benzyl- $N$-(2-chlorobenzyl)- $N$-(2-chloro-3-phenoxypropyl)amine 6a}

Yield $82 \%$, colourless oil. $\mathrm{R}_{\mathrm{f}} 0.78$ (hexane/EtOAc 1/1). ${ }^{1} \mathrm{H}$ NMR (300 MHz, $\mathrm{CDCl}_{3}$ ): $\delta 2.87$ and 3.06 (2H, 2 x d x d, J = 13.8, 7.2, 5.5 Hz); 3.61-3.84 (4H, m); 3.90-3.96 (1H, m); 4.10$4.18(2 \mathrm{H}, \mathrm{m})$; 6.76-6.78, 6.92-6.97, 7.13-7.39 and 7.51-7.54 $(2 \mathrm{H}, 1 \mathrm{H}, 10 \mathrm{H}$ and $1 \mathrm{H}, 4 \mathrm{x} \mathrm{m})$. ${ }^{13} \mathrm{C}$ NMR $\left(75 \mathrm{MHz}, \mathrm{CDCl}_{3}\right): \delta 57.0,56.5,57.5,59.6,69.9,114.6,121.1,126.7,127.3,128.3$, 128.4, 129.1, 129.4, 129.6, 131.0, 134.3, 136.4, 138.5, 158.3. IR (neat): $v_{\max }=2923,2849$, 1599, 1495, 1453, 1241, 1037, 749, $690 \mathrm{~cm}^{-1}$. MS (70 eV): $\mathrm{m} / \mathrm{z}(\%): 400 / 2 / 4\left(\mathrm{M}^{+}+1,100\right)$; 364/6 (75). Anal. Calcd for $\mathrm{C}_{23} \mathrm{H}_{23} \mathrm{Cl}_{2} \mathrm{NO}$ : C 69.00, H 5.79, N 3.50. Found: C 69.17, H 5.97, N 3.72 .

\section{$N$-Benzyl- $N$-(4-chlorobenzyl)- $N$-(2-chloro-3-phenoxypropyl)amine $6 \mathrm{~b}$}

Yield $79 \%$, colourless oil. $\mathrm{R}_{\mathrm{f}} 0.79$ (hexane/EtOAc 1/1). ${ }^{1} \mathrm{H}$ NMR (300 $\mathrm{MHz}, \mathrm{CDCl}_{3}$ ): $\delta 2.81$ and $3.02(2 \mathrm{H}, 2 \mathrm{x} \mathrm{d} \times \mathrm{d}, \mathrm{J}=13.8,7.2,6.0 \mathrm{~Hz}) ; 3.55$ and $3.68(2 \mathrm{H}, 2 \mathrm{x} \mathrm{d}, \mathrm{J}=13.5 \mathrm{~Hz}) ; 3.59$ and $3.64(2 \mathrm{H}, 2 \mathrm{x} \mathrm{d}, \mathrm{J}=13.8 \mathrm{~Hz})$; 3.96-4.01 (1H, m); 4.05-4.18 (2H, m) ; 6.76-6.79, 6.93-6.98 and 7.21-7.38 $(2 \mathrm{H}, 1 \mathrm{H}$ and $11 \mathrm{H}, 3 \mathrm{x} \mathrm{m}) .{ }^{13} \mathrm{C} \mathrm{NMR}\left(75 \mathrm{MHz}\right.$, ref $\left.=\mathrm{CDCl}_{3}\right): \delta 57.1,57.4,58.7$, 59.4, 70.0, 114.7, 121.3, 127.5, 128.5, 128.6, 129.1, 129.6, 130.4, 133.0, 137.5, 138.7, 158.3. IR (neat): $v_{\max }=2924,2828,1599,1588,1491,1453,1241,1088,801,751,691 \mathrm{~cm}^{-1}$. MS $(70$ $\mathrm{eV}): m / z(\%): 400 / 2 / 4\left(\mathrm{M}^{+}+1,100\right)$; 364/6 (60). Anal. Calcd for $\mathrm{C}_{23} \mathrm{H}_{23} \mathrm{Cl}_{2} \mathrm{NO}: \mathrm{C}$ 69.00, $\mathrm{H}$ 5.79, N 3.50. Found: C 68.92, H 5.94, N 3.55.

\section{$N$-Benzyl- $N$-(4-chlorobenzyl)- $N$-[2-chloro-3-(4-chlorophenoxy)propyl]amine 6c}

Yield $83 \%$, colourless oil. $\mathrm{R}_{\mathrm{f}} 0.80$ (hexane/EtOAc 1/1). ${ }^{1} \mathrm{H} \mathrm{NMR}\left(300 \mathrm{MHz}, \mathrm{CDCl}_{3}\right): \delta 2.80$ and 3.00 (2H, 2 x d x d, J = 13.6, 7.4, 5.5 Hz); 3.51-3.71 (4H, m); 3.91-3.96 (1H, m); 4.02$4.13(2 \mathrm{H}, \mathrm{m}) ; 6.65-6.68$ and 7.18-7.31 $(2 \mathrm{H}$ and $11 \mathrm{H}, 2 \mathrm{x} \mathrm{m}) .{ }^{13} \mathrm{C} \mathrm{NMR}\left(75 \mathrm{MHz}, \mathrm{CDCl}_{3}\right): \delta$ 56.7, 57.1, 58.7, 59.4, 70.0, 115.8, 126.1, 127.4, 128.4, 128.5, 128.9, 129.3, 130.2, 132.9, 137.3, 138.5, 156.8. IR (neat): $v_{\max }=2925,2828,2359,1596,1490,1453,1285,1241,1090$, 821, 801, 740, $698 \mathrm{~cm}^{-1}$. MS (70 eV): $\mathrm{m} / \mathrm{z}(\%): 434 / 36 / 38 / 40\left(\mathrm{M}^{+}+1,100\right) ; 398 / 400(90)$. Anal. Calcd for $\mathrm{C}_{23} \mathrm{H}_{22} \mathrm{Cl}_{3} \mathrm{NO}$ : C 63.54, H 5.10, N 3.22. Found: C 63.78, H 5.41, N 3.38.

\section{$N$-Benzyl- $N$-(4-methoxybenzyl)- $N$-(2-chloro-3-phenoxypropyl)amine 6d}

Yield $84 \%$, colourless oil. $\mathrm{R}_{\mathrm{f}} 0.75$ (hexane/EtOAc 1/1). ${ }^{1} \mathrm{H}$ NMR $\left(300 \mathrm{MHz}, \mathrm{CDCl}_{3}\right): \delta 2.80$ and $3.00(2 \mathrm{H}, 2 \mathrm{x} \mathrm{d} \mathrm{x} \mathrm{d}, \mathrm{J}=13.6,8.0,5.5 \mathrm{~Hz}) ; 3.48-3.75(4 \mathrm{H}, \mathrm{m}) ; 3.77(3 \mathrm{H}, \mathrm{s}) ; 3.86-3.95(1 \mathrm{H}$, $\mathrm{m})$; 4.09-4.17 (2H, m); 6.78-6.84, 6.92-6.97 and 7.21-7.32 (4H, $1 \mathrm{H}$ and $9 \mathrm{H}, 3 \mathrm{x} \mathrm{m}) .{ }^{13} \mathrm{C} \mathrm{NMR}$ 
$\left(75 \mathrm{MHz}, \mathrm{CDCl}_{3}\right): \delta 55.2,57.2,58.7,59.3,70.0,113.7,114.7,121.1,127.2,128.3,129.0$, 129.4, 130.1, 130.8, 138.9, 158.3, 158.8. IR (neat): $v_{\max }=2932,2833,2342,1599,1510$, 1495, 1454, 1241, 1172, 1035, 813, 752, 741, $691 \mathrm{~cm}^{-1}$. MS (70 eV): $\mathrm{m} / z(\%): 360$ (100); 396/8 $\left(\mathrm{M}^{+}+1,49\right)$. Anal. Calcd for $\mathrm{C}_{24} \mathrm{H}_{26} \mathrm{ClNO}_{2}$ : C 72.81, H 6.62, N 3.54. Found: C 72.94, H 6.82, N 3.40 .

\section{Synthesis of $N$-(2-iodo-3-aryloxypropyl)amines 7}

As a representative example, the synthesis of $N$-benzyl- $N$-(2-chlorobenzyl)- $N$-(2-iodo-3phenoxypropyl)amine 7a is described here. To a solution of $N$-benzyl- $N$-(2-chlorobenzyl)- $N$ (2-bromo-3-phenoxypropyl)amine 5a $(0.44 \mathrm{~g}, 1 \mathrm{mmol})$ in acetonitrile $(20 \mathrm{~mL})$ was added sodium iodide ( $3.00 \mathrm{~g}, 20$ equiv) at room temperature under stirring, and the resulting mixture was heated under reflux for $3 \mathrm{~h}$. Afterwards, the reaction mixture was poured into water (50 $\mathrm{mL})$ and extracted with $\mathrm{Et}_{2} \mathrm{O}(3 \times 50 \mathrm{~mL})$. Drying $\left(\mathrm{MgSO}_{4}\right)$, filtration of the drying agent and evaporation of the solvent afforded $N$-benzyl- $N$-(2-chlorobenzyl)- $N$-(2-iodo-3phenoxypropyl)amine 7a, which was purified by means of column chromatography on silica gel (hexane/EtOAc 1/1), (89\% yield, $0.40 \mathrm{~g}$ ) in order to obtain an analytically pure sample.

\section{$N$-Benzyl- $N$-(2-chlorobenzyl)- $N$-(2-iodo-3-phenoxypropyl)amine 7a}

Yield $89 \%$, colourless oil. $\mathrm{R}_{\mathrm{f}} 0.76$ (hexane/EtOAc 1/1). ${ }^{1} \mathrm{H}$ NMR (300 MHz, $\mathrm{CDCl}_{3}$ ): $\delta 3.01$ and $3.07(2 \mathrm{H}, 2 \mathrm{x} \mathrm{d} \mathrm{x} \mathrm{d}, \mathrm{J}=14.0,8.5,6.9 \mathrm{~Hz}) ; 3.63$ and $3.70(2 \mathrm{H}, 2 \mathrm{x} \mathrm{d}, \mathrm{J}=13.2 \mathrm{~Hz}) ; 3.74$ and $3.81(2 \mathrm{H}, 2 \mathrm{x} \mathrm{d}, \mathrm{J}=14.1 \mathrm{~Hz})$; 4.05-4.18 (2H, m); 4.22-4.30 (1H, m); 6.76-6.79, 6.93-6.97, 7.12-7.41 and 7.54-7.57 (2H, 1H, $10 \mathrm{H}$ and $1 \mathrm{H}, 4 \mathrm{x} \mathrm{m}) .{ }^{13} \mathrm{C} \mathrm{NMR}\left(75 \mathrm{MHz}, \mathrm{CDCl}_{3}\right): \delta 28.7$, 56.1, 59.4, 59.6, 71.0, 114.8, 121.1, 126.7, 127.3, 128.3, 128.4, 129.2, 129.4, 129.5, 131.2, 134.2, 136.3, 138.4, 158.1. IR (neat): $v_{\max }=2921,2849,1598,1494,1453,1239,1029,749$, $690 \mathrm{~cm}^{-1}$. MS (70 eV): $\mathrm{m} / \mathrm{z}(\%): 364 / 6(100) ; 492 / 4\left(\mathrm{M}^{+}+1\right.$, 5). Anal. Calcd for $\mathrm{C}_{23} \mathrm{H}_{23}$ CIINO: C 56.17, H 4.71, N 2.85. Found: C 55.96, H 4.83, N 3.01.

\section{$N$-Benzyl- $N$-(4-chlorobenzyl)- $N$-(2-iodo-3-phenoxypropyl)amine 7b}

Yield $88 \%$, colourless oil. $\mathrm{R}_{\mathrm{f}} 0.77$ (hexane/EtOAc 1/1). ${ }^{1} \mathrm{H}$ NMR (300 MHz, $\mathrm{CDCl}_{3}$ ): $\delta 2.93$ and $3.00(2 \mathrm{H}, 2 \mathrm{x} \mathrm{d} \times \mathrm{d}, \mathrm{J}=13.8,7.7,7.2 \mathrm{~Hz}) ; 3.54$ and $3.63(2 \mathrm{H}, 2 \mathrm{x} \mathrm{d}, \mathrm{J}=13.8 \mathrm{~Hz}) ; 3.59$ $(2 \mathrm{H}, \mathrm{d}, \mathrm{J}=7.7 \mathrm{~Hz}) ; 4.08-4.20(2 \mathrm{H}, \mathrm{m}) ; 4.22-4.32$ (1H, m); 6.77-6.81, 6.94-6.99 and 7.21-7.42 $(2 \mathrm{H}, 1 \mathrm{H}$ and $11 \mathrm{H}, 3 \mathrm{x} \mathrm{m}) .{ }^{13} \mathrm{C} \mathrm{NMR}\left(75 \mathrm{MHz}\right.$, ref $\left.=\mathrm{CDCl}_{3}\right): \delta 28.7,58.3,59.0,59.3,71.1$, $114.8,121.3,127.5,128.5,128.6,129.1,129.6,130.4,133.0,137.4,138.5,158.1$. IR (neat): $v_{\max }=2924,2803,1598,1587,1491,1453,1239,1088,800,751,690 \mathrm{~cm}^{-1} . \mathrm{MS}(70 \mathrm{eV}): \mathrm{m} / \mathrm{z}$ 
(\%): 364/6 (100); 492/4 ( $\left.\mathrm{M}^{+}+1,8\right)$. Anal. Calcd for $\mathrm{C}_{23} \mathrm{H}_{23} \mathrm{ClINO}$ : C 56.17, $\mathrm{H}$ 4.71, N 2.85. Found: C 56.19, H 4.88, N 3.04.

\section{$N$-Benzyl- $N$-(4-chlorobenzyl)- $N$-[2-iodo-3-(4-chlorophenoxy)propyl]amine 7c}

Yield $82 \%$, colourless oil. $\mathrm{R}_{\mathrm{f}} 0.77$ (hexane/EtOAc 1/1). ${ }^{1} \mathrm{H}$ NMR (300 MHz, $\mathrm{CDCl}_{3}$ ): $\delta 2.92$ and $2.99(2 \mathrm{H}, 2 \mathrm{x} \mathrm{d} \mathrm{x} \mathrm{d}, \mathrm{J}=14.0,8.0,6.9 \mathrm{~Hz}) ; 3.52$ and $3.64(2 \mathrm{H}, 2 \mathrm{x} \mathrm{d}, \mathrm{J}=13.5 \mathrm{~Hz}) ; 3.58$ $(2 \mathrm{H}, \mathrm{s}) ; 3.38-3.70(4 \mathrm{H}, \mathrm{m}) ; 4.03-4.14(2 \mathrm{H}, \mathrm{m}) ; 4.18-4.26(1 \mathrm{H}, \mathrm{m}) ; 6.67-6.70$ and 7.18-7.38 $(2 \mathrm{H}$ and $11 \mathrm{H}, 2 \mathrm{x} \mathrm{m}) .{ }^{13} \mathrm{C} \mathrm{NMR}\left(75 \mathrm{MHz}, \mathrm{CDCl}_{3}\right): \delta 28.0,58.3,59.0,59.1,71.1,115.9$, $126.1,127.4,128.4,128.5,129.0,129.3,130.3,132.9,137.2,138.4,156.6$. IR (neat): $v_{\max }=$ 2924, 2804, 2361, 1596, 1489, 1452, 1238, 1090, 821, 800, 737, $698 \mathrm{~cm}^{-1}$. MS (70 eV): $\mathrm{m} / \mathrm{z}$ (\%): no $\mathrm{M}^{+}$; 398/400/402 ( $\mathrm{M}^{+}$- I, 100). Anal. Calcd for $\mathrm{C}_{23} \mathrm{H}_{22} \mathrm{Cl}_{2} \mathrm{INO}$ : C 52.49, H 4.21, N 2.66. Found: C 52.36, H 4.18, N 2.53.

\section{$N$-Benzyl- $N$-(4-methoxybenzyl)- $N$-(2-iodo-3-phenoxypropyl)amine 7d}

Yield $79 \%$, colourless oil. $\mathrm{R}_{\mathrm{f}} 0.77$ (hexane/EtOAc 1/1). ${ }^{1} \mathrm{H}$ NMR (300 MHz, $\mathrm{CDCl}_{3}$ ): $\delta 2.95$ and $3.01(2 \mathrm{H}, .2 \times \mathrm{d} \mathrm{x} \mathrm{d}, \mathrm{J}=13.9,8.5,6.6 \mathrm{~Hz}) ; 3.48-3.72(4 \mathrm{H}, \mathrm{m}) ; 3.76(3 \mathrm{H}, \mathrm{s}) ; 4.01-4.29$ $(3 \mathrm{H}, \mathrm{m}) ; 6.78-6.83,6.92-6.97$ and 7.22-7.35 $(4 \mathrm{H}, 1 \mathrm{H}$ and $9 \mathrm{H}, 3 \mathrm{x} \mathrm{m}) .{ }^{13} \mathrm{C} \mathrm{NMR}(75 \mathrm{MHz}$, $\left.\mathrm{CDCl}_{3}\right): \delta 29.1,55.2,58.3,58.9,59.3,71.1,113.7,114.7,121.1,127.2,128.3,129.0,129.4$, 130.2, 130.7, 138.8, 158.2, 158.8. IR (neat): $v_{\max }=2928,2833,1598,1509,1495,1240,1171$, 1033, 812, 752, 734, $691 \mathrm{~cm}^{-1}$. MS (70 eV): $\mathrm{m} / z(\%): 360(100) ; 488\left(\mathrm{M}^{+}+1,10\right)$. Anal. Calcd for $\mathrm{C}_{24} \mathrm{H}_{26} \mathrm{INO}_{2}$ : C 59.14, H 5.38, N 2.87. Found: C 59.30, H 5.62, N 3.00.

\section{Synthesis of 2-amino-3-aryloxy-1-fluoropropanes 8 and $N$-(2-fluoro-3- aryloxypropyl)amines 9}

As a representative example, the synthesis of 2-[N-benzyl- $N$-(2-chlorobenzyl)amino]-1fluoro-3-phenoxypropane $\quad \mathbf{8 a} \quad$ and $\quad N$-benzyl- $N$-(2-chlorobenzyl)- $N$-(2-fluoro-3phenoxypropyl)amine 9a is described here. To a solution of $N$-benzyl- $N$-(2-chlorobenzyl)- $N$ (2-bromo-3-phenoxypropyl)amine 5a $(2.22 \mathrm{~g}, 5 \mathrm{mmol})$ in acetonitrile $(30 \mathrm{~mL})$ was added $\operatorname{TBAF}(2.61 \mathrm{~g}, 2$ equiv) at room temperature under stirring, and the resulting mixture was heated under reflux for $15 \mathrm{~h}$. Extraction with $\mathrm{Et}_{2} \mathrm{O}(3 \times 50 \mathrm{~mL})$, drying $\left(\mathrm{MgSO}_{4}\right)$, filtration of the drying agent and evaporation of the solvent afforded a mixture of 2-[N-benzyl- $N-(2-$ chlorobenzyl)amino]-1-fluoro-3-phenoxypropane 8a and $N$-benzyl- $N$-(2-chlorobenzyl)- $N$-(2fluoro-3-phenoxypropyl)amine 9a (5/1). Both isomers were separated by means of column 
chromatography (hexane/EtOAc 97/3) furnishing compounds 8a (54\% yield, 1.04 g) and 9a $(10 \%$ yield, $0.19 \mathrm{~g})$ in order to obtain analytically pure samples.

\section{2-[ $N$-Benzyl- $N$-(2-chlorobenzyl)amino]-1-fluoro-3-phenoxypropane 8a}

Yield $54 \%$, colourless oil. $\mathrm{R}_{\mathrm{f}} 0.17$ (hexane/EtOAc 97/3). ${ }^{1} \mathrm{H}$ NMR (300 $\left.\mathrm{MHz}, \mathrm{CDCl}_{3}\right): \delta$ 3.31-3.44 (1H, m); 3.88 and $4.01(4 \mathrm{H}, 2 \mathrm{x} \mathrm{s}) ; 4.20(2 \mathrm{H}, \mathrm{d}, \mathrm{J}=6.1 \mathrm{~Hz}) ; 4.77(2 \mathrm{H}, \mathrm{d} \times \mathrm{d}, \mathrm{J}=$ 47.4, 5.5 Hz); 6.86-6.89, 6.91-6.97, 7.12-7.38 and 7.61-7.63 (2H, $1 \mathrm{H}, 10 \mathrm{H}$ and $1 \mathrm{H}, 4 \mathrm{x} \mathrm{m})$. ${ }^{13} \mathrm{C}$ NMR $\left(75 \mathrm{MHz}, \mathrm{CDCl}_{3}\right): \delta 52.2,55.5,57.2(\mathrm{~d}, \mathrm{~J}=18.4 \mathrm{~Hz}), 65.3(\mathrm{~d}, \mathrm{~J}=5.8 \mathrm{~Hz}), 82.4(\mathrm{~d}, \mathrm{~J}$ $=170.7 \mathrm{~Hz}), 114.4,121.0,126.8,127.1,128.1,128.3,128.7,129.4,129.5,130.5,134.0$, 137.1, 139.6, 158.5. ${ }^{19} \mathrm{~F}\left(\mathrm{CCl}_{3} \mathrm{~F}\right):-227.32(\mathrm{t} \mathrm{x} \mathrm{d}, \mathrm{J}=48.0,23.7 \mathrm{~Hz})$; IR (neat): $v_{\max }=3062$, 3029, 2954, 1599, 1495, 1470, 1241, 1037, 751, 734, $691 \mathrm{~cm}^{-1}$. MS (70 eV): $\mathrm{m} / z(\%): 384 / 6$ $\left(\mathrm{M}^{+}+1,100\right)$. Anal. Calcd for $\mathrm{C}_{23} \mathrm{H}_{23} \mathrm{ClFNO}$ : C 71.96, $\mathrm{H}$ 6.04, N 3.65. Found: $\mathrm{C} 71.82, \mathrm{H}$ $6.19, \mathrm{~N} 3.56$.

\section{$N$-Benzyl- $N$-(2-chlorobenzyl)- $N$-(2-fluoro-3-phenoxypropyl)amine 9a}

Yield $10 \%$, colourless oil. $\mathrm{R}_{\mathrm{f}} 0.10$ (hexane/EtOAc 97/3). ${ }^{1} \mathrm{H}$ NMR (300 MHz, $\left.\mathrm{CDCl}_{3}\right): \delta$ 2.84-2.93 (2H, m); 3.71 and $3.82(4 \mathrm{H}, 2 \mathrm{x} \mathrm{s}) ; 3.92-4.06(2 \mathrm{H}, \mathrm{m}) ; 4.80-4.87$ and 4.96-5.03 (1H, $2 \times \mathrm{m}) ; 6.78-6.81,6.92-6.97,7.15-7.40$ and 7.52-7.55 $(2 \mathrm{H}, 1 \mathrm{H}, 10 \mathrm{H}$ and $1 \mathrm{H}, 4 \mathrm{x} \mathrm{m}) .{ }^{13} \mathrm{C}$ NMR $\left(75 \mathrm{MHz}\right.$, ref $\left.=\mathrm{CDCl}_{3}\right): \delta 54.0(\mathrm{~d}, \mathrm{~J}=21.9 \mathrm{~Hz}), 56.5,59.6,68.3(\mathrm{~d}, \mathrm{~J}=23.1 \mathrm{~Hz}), 90.9$ $(d, J=174.2 \mathrm{~Hz}), 114.6,121.2,126.8,127.4,128.5$, 129.1, 129.5, 129.6, 129.7, 131.0, 134.3, 136.7, 138.9, 158.5. ${ }^{19} \mathrm{~F}\left(\mathrm{CCl}_{3} \mathrm{~F}\right):-188.68$ to -188.2 (m). IR (neat): $v_{\max }=2923,2850,1598$, 1588, 1494, 1443, 1242, 1049, 1037, 750, $690 \mathrm{~cm}^{-1}$. MS (70 eV): $\mathrm{m} / z(\%): 384 / 6\left(\mathrm{M}^{+}+1,82\right)$.

\section{2-[N-Benzyl- $N$-(4-chlorobenzyl)amino]-1-fluoro-3-phenoxypropane 8b}

Yield $42 \%$, colourless oil. $\mathrm{R}_{\mathrm{f}} 0.35$ (hexane/EtOAc 96/4). ${ }^{1} \mathrm{H}$ NMR (300 MHz, $\left.\mathrm{CDCl}_{3}\right): \delta$ 3.28-3.43 (1H, m); 3.82 and $3.83(4 \mathrm{H}, 2 \mathrm{x} \mathrm{s}) ; 4.16(2 \mathrm{H}, \mathrm{d}, \mathrm{J}=6.1 \mathrm{~Hz}) ; 4.72(2 \mathrm{H}, \mathrm{d}$ x d, J = 47.4, 5.0 Hz); 6.85-6.88, 6.94-6.99 and 7.22-7.38 (2H, $1 \mathrm{H}$ and $11 \mathrm{H}, 3 \mathrm{x} \mathrm{m}) .{ }^{13} \mathrm{C} \mathrm{NMR}(75$ $\left.\mathrm{MHz}, \mathrm{CDCl}_{3}\right): \delta 54.7,55.3,56.4(\mathrm{~d}, \mathrm{~J}=18.5 \mathrm{~Hz}), 65.4(\mathrm{~d}, \mathrm{~J}=6.9 \mathrm{~Hz}), 82.5(\mathrm{~d}, \mathrm{~J}=172.0 \mathrm{~Hz})$, $114.4,121.0,127.2,128.4,128.5,128.6,129.5,130.0,132.7,138.4,139.6,158.4 .{ }^{19} \mathrm{~F}$ $\left(\mathrm{CCl}_{3} \mathrm{~F}\right):-227.30$ ( $\mathrm{t} \times \mathrm{d}, \mathrm{J}=47.3,22.3 \mathrm{~Hz}$ ). IR (neat): $v_{\max }=2928,2833,1599,1588,1491$, 1470, 1241, 1088, 1014, 907, 753, 730, $691 \mathrm{~cm}^{-1}$. MS (70 eV): $\mathrm{m} / z$ (\%): 364/6 (100); 384/6 $\left(\mathrm{M}^{+}+1\right.$, 77). Anal. Calcd for $\mathrm{C}_{23} \mathrm{H}_{23}$ ClFNO: C 71.96, H 6.04, N 3.65. Found: C 71.89, H 6.18, N 3.67 . 


\section{$N$-Benzyl- $N$-(4-chlorobenzyl)- $N$-(2-fluoro-3-phenoxypropyl)amine 9b}

Yield $8 \%$, colourless oil. $\mathrm{R}_{\mathrm{f}} 0.28$ (hexane/EtOAc 96/4). ${ }^{1} \mathrm{H}$ NMR (300 MHz, $\left.\mathrm{CDCl}_{3}\right): \delta 2.75-$ $2.95(2 \mathrm{H}, \mathrm{m}) ; 3.65$ and $3.67(4 \mathrm{H}, 2 \mathrm{x} \mathrm{s}) ; 3.91-4.06(2 \mathrm{H}, \mathrm{m}) ; 4.80-4.86$ and 4.93-5.02 $(1 \mathrm{H}, 2 \mathrm{x}$ $\mathrm{m})$; 6.79-6.82, 6.94-6.99 and 7.22-7.38 $(2 \mathrm{H}, 1 \mathrm{H}$ and $11 \mathrm{H}, 3 \mathrm{x} \mathrm{m}) .{ }^{13} \mathrm{C} \mathrm{NMR}(75 \mathrm{MHz}$, ref $=$ $\left.\mathrm{CDCl}_{3}\right): \delta 53.7(\mathrm{~d}, \mathrm{~J}=21.9 \mathrm{~Hz}), 58.7,59.4,68.2(\mathrm{~d}, \mathrm{~J}=23.1 \mathrm{~Hz}), 90.9(\mathrm{~d}, \mathrm{~J}=174.3 \mathrm{~Hz})$, $114.6,121.3,127.4,128.5,128.6,129.0,129.6,130.3,132.9,137.7,138.9,158.4 .{ }^{19} \mathrm{~F}$ $\left(\mathrm{CCl}_{3} \mathrm{~F}\right):-188.58$ to -188.18 (m). IR (neat): $v_{\max }=2924,2829,1598,1588,1490,1453,1242$, 1088, 1014, 801, 752, $691 \mathrm{~cm}^{-1}$. MS (70 eV): $\mathrm{m} / z(\%): 364 / 6(100) ; 384 / 6\left(\mathrm{M}^{+}+1,55\right)$.

\section{2-[N-Benzyl- $N$-(4-chlorobenzyl)amino]-3-(4-chlorophenoxy)-1-fluoropropane 8c}

Yield $60 \%$, colourless oil. $\mathrm{R}_{\mathrm{f}} 0.33$ (hexane/EtOAc 96/4). ${ }^{1} \mathrm{H}$ NMR (300 MHz, $\left.\mathrm{CDCl}_{3}\right): \delta$ 3.25-3.40 (1H, m); 3.81 and $3.82(4 \mathrm{H}, 2 \mathrm{x} \mathrm{s}) ; 4.11(2 \mathrm{H}, \mathrm{d}, \mathrm{J}=6.0 \mathrm{~Hz}) ; 4.71(2 \mathrm{H}, \mathrm{d}$ x d, J = 47.3, 4.9 Hz); 6.75-6.80 and 7.19-7.37 (2H and 11H, 2 x m). $\left.{ }^{13} \mathrm{C} \mathrm{NMR} \mathrm{(75} \mathrm{MHz}, \mathrm{CDCl}_{3}\right): \delta$ 54.7, 55.3, $56.4(\mathrm{~d}, \mathrm{~J}=18.5 \mathrm{~Hz}), 66.0(\mathrm{~d}, \mathrm{~J}=7.0 \mathrm{~Hz}), 82.3$ (d, J = 171.9 Hz), 115.7, 125.9, 127.2, 128.4, 128.5, 128.6, 129.4, 129.9, 132.7, 138.3, 139.4, 157.0. ${ }^{19} \mathrm{~F}\left(\mathrm{CCl}_{3} \mathrm{~F}\right):-227.31(\mathrm{t} \mathrm{x}$ $\mathrm{d}, \mathrm{J}=47.3,22.3 \mathrm{~Hz}$ ). IR (neat): $v_{\max }=2930,2831,1596,1588,1490,1470,1241,1090,1014$, 1006, 821, 737, $698 \mathrm{~cm}^{-1}$. MS (70 eV): $\mathrm{m} / \mathrm{z}(\%): 418 / 20 / 22\left(\mathrm{M}^{+}+1,100\right)$. Anal. Calcd for $\mathrm{C}_{23} \mathrm{H}_{22} \mathrm{Cl}_{2} \mathrm{FNO}$ : C 66.04, H 5.30, N 3.35. Found: C 66.11, H 5.54, N 3.57.

\section{$N$-Benzyl- $N$-(4-chlorobenzyl)- $N$-[2-fluoro-3-(4-chlorophenoxy)propyl]amine 9c}

Yield $10 \%$, colourless oil. $\mathrm{R}_{\mathrm{f}} 0.27$ (hexane/EtOAc 96/4). ${ }^{1} \mathrm{H}$ NMR (300 $\left.\mathrm{MHz}, \mathrm{CDCl}_{3}\right): \delta$ 2.74-2.96 (2H, m); 3.64 and $3.66(4 \mathrm{H}, 2 \mathrm{x} \mathrm{s}) ; 3.90-4.05(2 \mathrm{H}, \mathrm{m}) ; 4.75-4.82$ and 4.91-5.03 (1H, $2 \mathrm{x} \mathrm{m}) ; 6.69-6.72$ and 7.20-7.37 (2H and $11 \mathrm{H}, 2 \mathrm{x} \mathrm{m}) .{ }^{13} \mathrm{C} \mathrm{NMR}\left(75 \mathrm{MHz}, \mathrm{CDCl}_{3}\right): \delta 53.4(\mathrm{~d}$, $\mathrm{J}=21.9 \mathrm{~Hz}), 58.7,59.4,68.5(\mathrm{~d}, \mathrm{~J}=24.2 \mathrm{~Hz}), 90.7(\mathrm{~d}, \mathrm{~J}=175.4 \mathrm{~Hz}), 115.7,127.3,128.4$, $128.5,128.9,129.3,129.6,130.2,132.9,137.5,138.7,156.9 .{ }^{19} \mathrm{~F}\left(\mathrm{CCl}_{3} \mathrm{~F}\right):-188.96$ to -188.73 (m). IR (neat): $v_{\max }=2925,2828,1594,1488,1452,1240,1090,1014,907,822,732,698$ $\mathrm{cm}^{-1}$. MS (70 eV): $\mathrm{m} / z(\%): 418 / 20 / 22\left(\mathrm{M}^{+}+1,100\right)$.

\section{2-[N-Benzyl- $N$-(4-methoxybenzyl)amino]-1-fluoro-3-phenoxypropane 8d}

Yield $61 \%$, colourless oil. $\mathrm{R}_{\mathrm{f}} 0.13$ (hexane/EtOAc 97/3). ${ }^{1} \mathrm{H}$ NMR $\left(300 \mathrm{MHz}, \mathrm{CDCl}_{3}\right): \delta$ 3.29-3.44 (1H, m); $3.78(5 \mathrm{H}, \mathrm{s}) ; 3.84(2 \mathrm{H}, \mathrm{s}) ; 4.15(2 \mathrm{H}, \mathrm{d}, \mathrm{J}=6.6 \mathrm{~Hz}) ; 4.71(2 \mathrm{H}, \mathrm{d}$ x d, J = 47.6, $5.2 \mathrm{~Hz})$; 6.83-6.87, 6.92-6.97 and 7.20-7.39 (4H, $1 \mathrm{H}$ and $9 \mathrm{H}, 3 \mathrm{x} \mathrm{m}) .{ }^{13} \mathrm{C} \mathrm{NMR}(75$ $\left.\mathrm{MHz}, \mathrm{CDCl}_{3}\right): \delta 54.7,55.1,55.2,56.2(\mathrm{~d}, \mathrm{~J}=18.5 \mathrm{~Hz}), 65.5(\mathrm{~d}, \mathrm{~J}=7.0 \mathrm{~Hz}), 82.6(\mathrm{~d}, \mathrm{~J}=171.9$ $\mathrm{Hz}), 113.7,114.4,120.9,127.0,128.3,128.6,129.5,129.8,131.8,140.0,158.5,158.7 .{ }^{19} \mathrm{~F}$ 
$\left(\mathrm{CCl}_{3} \mathrm{~F}\right):-227.27$ (t x d, J = 47.4, $23.7 \mathrm{~Hz}$ ). IR (neat): $v_{\max }=2917,2849,1599,1510,1495$, 1454, 1241, 1171, 1035, 831, 819, 753, 737, $691 \mathrm{~cm}^{-1}$. MS $(70 \mathrm{eV}): \mathrm{m} / \mathrm{z}(\%): 380\left(\mathrm{M}^{+}+1\right.$, 100). Anal. Calcd for $\mathrm{C}_{24} \mathrm{H}_{26} \mathrm{FNO}_{2}$ : C 75.96, H 6.91, N 3.69. Found: C 75.77, H 7.03, N 3.51.

\section{$N$-Benzyl- $N$-(4-methoxybenzyl)- $N$-(2-fluoro-3-phenoxypropyl)amine 9d}

Yield $14 \%$, colourless oil. $\mathrm{R}_{\mathrm{f}} 0.09$ (hexane/EtOAc 97/3). ${ }^{1} \mathrm{H}$ NMR $\left(300 \mathrm{MHz}, \mathrm{CDCl}_{3}\right): \delta$ 2.73-2.94 (2H, m); 3.61 and $3.67(4 \mathrm{H}, 2 \times$ s); $3.78(3 \mathrm{H}, \mathrm{s}) ; 3.94-4.04(2 \mathrm{H}, \mathrm{m}) ; 4.77-4.83$ and 4.93-5.00 (1H, 2 x m); 6.78-6.85, 6.93-6.98 and 7.22-7.36 (4H, $1 \mathrm{H}$ and $9 \mathrm{H}, 3 \mathrm{x} \mathrm{m}) .{ }^{13} \mathrm{C} \mathrm{NMR}$ $\left(75 \mathrm{MHz}, \mathrm{ref}=\mathrm{CDCl}_{3}\right): \delta 53.6(\mathrm{~d}, \mathrm{~J}=23.1 \mathrm{~Hz}), 55.3,58.8,59.4,68.5(\mathrm{~d}, \mathrm{~J}=23.1 \mathrm{~Hz}), 91.0$ $(\mathrm{d}, \mathrm{J}=174.2 \mathrm{~Hz}), 113.8,114.6,121.1,127.2$, 128.4, 129.0, 129.5, 130.2, 131.1, 139.3, 158.5, 158.8. ${ }^{19} \mathrm{~F}\left(\mathrm{CCl}_{3} \mathrm{~F}\right):-188.52$ to $-188.05(\mathrm{~m})$. IR (neat): $v_{\max }=2951,2834,1599,1510,1495$, 1453, 1243, 1172, 1035, 812, 752, 742, $691 \mathrm{~cm}^{-1}$. MS (70 eV): $\left./ z / z\right): 380\left(\mathbf{M}^{+}+1,100\right)$.

\section{Synthesis of chiral $\beta$-halo amines 15 and 16}

General procedure. To a solution of either 2(R)-methoxymethyl-1-[1(R)-phenylethyl]aziridine 13a or ethyl 1-[1(R)-phenylethyl]aziridine-2( $R$ )-carboxylate $\mathbf{1 3 b}$ in $\mathrm{CH}_{3} \mathrm{CN}(3 \mathrm{M})$ was added methyl trifluoromethanesulfonate (1.1 equiv) at room temperature under nitrogen atmosphere in oven-dried glassware. This solution was stirred for $10 \mathrm{~min}$ at room temperature before adding tetra- $n$-butylammonium halide ( 1.5 equiv) at $0{ }^{\circ} \mathrm{C}$. The resulting reaction mixture was stirred at room temperature for one hour. Subsequently, the reaction mixture was extracted with $\mathrm{CH}_{2} \mathrm{Cl}_{2}$ and water, and the combined organic layers were dried over anhydrous $\mathrm{MgSO}_{4}$. Filtration of the drying agent and removal of the solvent in vacuo afforded the crude product, which was purified by column chromatography on silica gel to provide an analytically pure sample.

$N$-[2(S)-Bromo-3-methoxypropyl]- $N$-methyl- $N$-[1(R)-phenylethyl]amine 16a. Yield 47\%, colorless oil; $[\alpha]^{25}+13\left(\mathrm{c} 0.722, \mathrm{CHCl}_{3}\right) .{ }^{1} \mathrm{H}$ NMR $\left(400 \mathrm{MHz}, \mathrm{CDCl}_{3}\right): \delta 1.36(3 \mathrm{H}, \mathrm{d}, \mathrm{J}=6.8$ $\mathrm{Hz}) ; 2.21(3 \mathrm{H}, \mathrm{s}) ; 2.69$ (1H, d x d, J=13.6, $6.0 \mathrm{~Hz}) ; 2.93(1 \mathrm{H}, \mathrm{d} x \mathrm{~d}, \mathrm{~J}=13.2,8.8 \mathrm{~Hz}) ; 3.38$ (3H, s); 3.6-3.67 (2H, m); $3.67(1 \mathrm{H}, \mathrm{d} x \mathrm{~d}, \mathrm{~J}=10.8,4.1 \mathrm{~Hz})$; 4.06-4.12 (1H, m); 7.22-7.32 (5H, m). ${ }^{13} \mathrm{C}$ NMR (100 MHz, $\left.\mathrm{CDCl}_{3}\right): \delta 17.4,38.9,51.0,58.3,58.9,63.5,74.7,127.0,127.7,128.1$, 143.2. MS $m / z$ (\%) 287(0.3), 285 (0.3), 270 (1), 272 (1), 148 (75), 105(100). HRMS (ESI) calcd for $\mathrm{C}_{13} \mathrm{H}_{20} \mathrm{BrNONa}(\mathrm{M}+\mathrm{Na})^{+} 308.0626$, found 308.0624 . 
$N$-[2(S)-Iodo-3-methoxypropyl]- $N$-methyl- $N$-[1(R)-phenylethyl]amine 16b. Yield 52\%, colorless oil; $[\alpha]^{25}{ }_{\mathrm{D}}^{-4}$ (c 3.26, in $\left.\mathrm{CHCl}_{3}\right)$. ${ }^{1} \mathrm{H} \mathrm{NMR}\left(400 \mathrm{MHz}, \mathrm{CDCl}_{3}\right): \delta 1.36(3 \mathrm{H}, \mathrm{d}, \mathrm{J}=6.8$ $\mathrm{Hz}) ; 2.17(3 \mathrm{H}, \mathrm{s}) ; 2.72-2.87(2 \mathrm{H}, \mathrm{m}) ; 3.38(3 \mathrm{H}, \mathrm{s}) ; 3.61-3.73(3 \mathrm{H}, \mathrm{m}) ; 4.16-4.22(1 \mathrm{H}, \mathrm{m})$; 7.21-7.37 (5H, m). $\left.{ }^{13} \mathrm{C} \mathrm{NMR} \mathrm{(100} \mathrm{MHz,} \mathrm{CDCl}_{3}\right): \delta 17.6,31.8,38.9,59.0,60.0,63.6,75.9$, 127.2, 128.0, 128.4, 143.4. HRMS (ESI) calcd for $\mathrm{C}_{13} \mathrm{H}_{20} \mathrm{INONa}(\mathrm{M}+\mathrm{Na})^{+} 356.0487$, found 356.0488 .

$N$-[1(R)-Fluoromethyl-2-methoxyethyl]- $N$-methyl- $N$-[1(R)-phenylethyl $]$ amine $15 \mathrm{c}$. Yield $58 \%$, colorless oil; $[\alpha]^{25}{ }_{\mathrm{D}}+51\left(\mathrm{c} 0.758\right.$, in $\left.\mathrm{CHCl}_{3}\right) .{ }^{1} \mathrm{H} \mathrm{NMR}\left(200 \mathrm{MHz}, \mathrm{CDCl}_{3}\right): \delta 1.37(3 \mathrm{H}$, d, J=6.8 Hz); $2.32(3 \mathrm{H}, \mathrm{s}) ; 3.09-3.26(1 \mathrm{H}, \mathrm{m}) ; 3.29(3 \mathrm{H}, \mathrm{s}) ; 3.39-3.52(2 \mathrm{H}, \mathrm{m}) ; 3.87(1 \mathrm{H}, \mathrm{q}$, $\mathrm{J}=6.8 \mathrm{~Hz}) ; 4.36(1 \mathrm{H}, \mathrm{d} x \mathrm{~d} x \mathrm{~d}, \mathrm{~J}=46.8,9.6,4.6 \mathrm{~Hz}) ; 4.40(1 \mathrm{H}, \mathrm{d}$ x d x d, J=46.8, 9.6, 4.6 Hz); 7.17-7.37 (5H, m). ${ }^{13} \mathrm{C} \mathrm{NMR}\left(50 \mathrm{MHz}, \mathrm{CDCl}_{3}\right): \delta 20.8,34.2,57.4,57.8,58.9,62.4,69.9$, 70.1, 81.4, 84.8, 126.8, 127.3, 128.3, 145.4. HRMS (ESI) calcd for $\mathrm{C}_{13} \mathrm{H}_{20} \mathrm{FNONa}(\mathrm{M}+\mathrm{Na})^{+}$ 248.1427 , found 248.1424 .

$N$-[2(S)-Fluoro-3-methoxypropyl]- $N$-methyl- $N$-[1(R)-phenylethyl]amine 16c. Yield 19\%, colorless oil; $[\alpha]_{\mathrm{D}}^{25}+25\left(\mathrm{c} 0.86\right.$, in $\left.\mathrm{CHCl}_{3}\right) .{ }^{1} \mathrm{H}$ NMR $\left(200 \mathrm{MHz}, \mathrm{CDCl}_{3}\right) \delta 1.37(3 \mathrm{H}, \mathrm{d}, \mathrm{J}=6.8$ $\mathrm{Hz}) ; 2.27(3 \mathrm{H}, \mathrm{s}) ; 2.45-2.77(2 \mathrm{H}, \mathrm{m}) ; 3.36(3 \mathrm{H}, \mathrm{s}) ; 3.42-3.68(3 \mathrm{H}, \mathrm{m}) ; 4.53-4.87(1 \mathrm{H}, \mathrm{m})$; 7.20-7.36 (5H, m). ${ }^{13} \mathrm{C}$ NMR (50 MHz, $\left.\mathrm{CDCl}_{3}\right): \delta 17.9,39.6,39.6,54.5,54.9,59.3,63.8$, 73.0, 73.4, 90.2, 93.6, 126.9, 127.7, 128.1, 143.3. HRMS (ESI) calcd for $\mathrm{C}_{13} \mathrm{H}_{20} \mathrm{FNONa}(\mathrm{M}$ $+\mathrm{Na})^{+} 248.1427$, found 248.1422 .

$N$-[1(R)-Chloromethyl-2-methoxyethyl]- $N$-methyl- $N$-[1(R)-phenylethyl]amine

$15 d$.

Spectral data derived from a crude reaction mixture. Colorless oil; ${ }^{1} \mathrm{H}$ NMR $(400 \mathrm{MHz}$, $\left.\mathrm{CD}_{3} \mathrm{CN}\right): \delta 1.36(3 \mathrm{H}, \mathrm{d}, \mathrm{J}=6.8 \mathrm{~Hz}) ; 2.39(3 \mathrm{H}, \mathrm{s}) ; 3.30(3 \mathrm{H}, \mathrm{s}) ; 3.23(1 \mathrm{H}, \mathrm{q}, \mathrm{J}=6.8 \mathrm{~Hz}) ; 3.48-$ $3.68(3 \mathrm{H}, \mathrm{m}) ; 4.08-4.14(1 \mathrm{H}, \mathrm{m}) ; 7.21-7.35(5 \mathrm{H}, \mathrm{m})$.

$N$-[2(S)-Chloro-3-methoxypropyl]- $N$-methyl- $N$-[1(R)-phenylethyl]amine 16d. Yield 73\%, colorless oil; $[\alpha]^{25} 22\left(\mathrm{c} 1.20\right.$, in $\left.\mathrm{CHCl}_{3}\right) .{ }^{1} \mathrm{H}$ NMR $\left(400 \mathrm{MHz}, \mathrm{CDCl}_{3}\right): \delta 1.36(3 \mathrm{H}, \mathrm{d}, \mathrm{J}=6.8$ $\mathrm{Hz}) ; 2.44(3 \mathrm{H}, \mathrm{s}) ; 2.57$ (1H, d x d, J=13.6, $6.0 \mathrm{~Hz}) ; 2.86(1 \mathrm{H}, \mathrm{d} x \mathrm{~d}, \mathrm{~J}=13.2,8.4 \mathrm{~Hz}) ; 3.38$ (3H, s); $3.53(1 \mathrm{H}, \mathrm{d} x \mathrm{~d}, \mathrm{~J}=10.8,6.4 \mathrm{~Hz}) ; 3.66(1 \mathrm{H}, \mathrm{q}, \mathrm{J}=6.8 \mathrm{~Hz}) ; 3.73(1 \mathrm{H}, \mathrm{d}$ x d, J=10.4, $4.0 \mathrm{~Hz})$; 3.99-4.05 (1H, m); 7.21-7.34 (5H, m). ${ }^{13} \mathrm{C} \mathrm{NMR}\left(100 \mathrm{MHz}, \mathrm{CDCl}_{3}\right)$ : $\delta 17.7,39.4,58.1,58.6$, 59.3, 63.9, 74.9, 127.2, 127.9, 128.4, 143.4. HRMS (ESI) calcd for $\mathrm{C}_{13} \mathrm{H}_{20} \mathrm{ClNONa}(\mathrm{M}+\mathrm{Na})^{+}$ 264.1131, found 264.1129. 
Ethyl 2(S)-bromo-3-\{N-methyl- $N$-[1(R)-phenylethyl $]$ amino $\}$ propionate 16 e. This compound was isolated with small amount of the dehydrobrominated product. Yield 92\%, colorless oil; $[\alpha]_{\mathrm{D}}+32\left(\mathrm{c} 0.524\right.$, in $\left.\mathrm{CHCl}_{3}\right) .{ }^{1} \mathrm{H}$ NMR $\left(200 \mathrm{MHz}, \mathrm{CDCl}_{3}\right): \delta 1.26-1.37(6 \mathrm{H}, \mathrm{m})$; $2.16(3 \mathrm{H}, \mathrm{s}) ; 2.70-2.79(1 \mathrm{H}, \mathrm{m}) ; 3.19-3.31(1 \mathrm{H}, \mathrm{m}) ; 3.58-3.88(1 \mathrm{H}, \mathrm{m}) ; 4.11-4.30(3 \mathrm{H}, \mathrm{m})$; 7.18-7.38 (5H, m).

Ethyl 2(S)-iodo-3-\{N-methyl- $N$-[1(R)-phenylethyl]amino\}propionate 16f. This compound was isolated with small amount of the dehydroidodinated product. Yield 90\%, colorless oil; $[\alpha]_{\mathrm{D}}+19\left(\mathrm{c} 2.53\right.$, in $\left.\mathrm{CHCl}_{3}\right) .{ }^{1} \mathrm{H}$ NMR $\left(400 \mathrm{MHz}, \mathrm{CDCl}_{3}\right): \delta 1.26-1.31(3 \mathrm{H}, \mathrm{m}) ; 1.37(3 \mathrm{H}, \mathrm{d}$, $\mathrm{J}=6.8 \mathrm{~Hz}) ; 2.14(3 \mathrm{H}, \mathrm{s}) ; 2.75-2.86(1 \mathrm{H}, \mathrm{m}) ; 3.07-3.23(1 \mathrm{H}, \mathrm{m}) ; 3.72-3.86(1 \mathrm{H}, \mathrm{m}) ; 4.14-4.30$ $(3 \mathrm{H}, \mathrm{m}) ; 7.22-7.38(5 \mathrm{H}, \mathrm{m})$.

Ethyl 2(S)-fluoro-3-\{N-methyl- $N$-[1(R)-phenylethyl]amino\}propionate $16 \mathrm{~g}$. Yield $71 \%$, colorless oil; $[\alpha]^{25}{ }_{\mathrm{D}}+6\left(\mathrm{c} 1.24\right.$, in $\left.\mathrm{CHCl}_{3}\right) .{ }^{1} \mathrm{H} \mathrm{NMR}\left(400 \mathrm{MHz}, \mathrm{CDCl}_{3}\right): \delta 1.29(3 \mathrm{H}, \mathrm{t}, \mathrm{J}=7.6$ $\mathrm{Hz}) ; 1.38(3 \mathrm{H}, \mathrm{d}, \mathrm{J}=6.8 \mathrm{~Hz}) ; 2.30(3 \mathrm{H}, \mathrm{s}) ; 2.98(2 \mathrm{H}, \mathrm{d}$ x d, J=25.6, $4.4 \mathrm{~Hz}) ; 3.75$ (1H, q, J=6.8 $\mathrm{Hz}) ; 4.23(1 \mathrm{H}, \mathrm{q} x \mathrm{~d}, \mathrm{~J}=7.6,5.6 \mathrm{~Hz}) ; 5.03(1 \mathrm{H}, \mathrm{d} x \mathrm{t}, \mathrm{J}=49.6,4.8 \mathrm{~Hz}) ; 7.23-7.32(5 \mathrm{H}, \mathrm{m}) .{ }^{13} \mathrm{C}$ NMR $\left(100 \mathrm{MHz}, \mathrm{CDCl}_{3}\right): \delta 14.1,17.4,39.5,39.5,39.5,55.2,55.4,61.4,63.3,88.4,88.5$, 90.27, 90.31, 126.9, 127.6, 128.1, 143.0, 168.8, 169.1. HRMS (ESI) calcd for $\mathrm{C}_{14} \mathrm{H}_{20} \mathrm{FNO}_{2} \mathrm{Na}$ $(\mathrm{M}+\mathrm{Na})^{+} 276.1376$, found 276.1377 .

Ethyl 2(S)-chloro-3-\{N-methyl- $N$-[1(R)-phenylethyl]amino\}propionate 16 h. Yield $93 \%$, colorless oil; $[\alpha]^{25}+16$ (c 1.472, in $\left.\mathrm{CHCl}_{3}\right)$. ${ }^{1} \mathrm{H}$ NMR $\left(200 \mathrm{MHz}, \mathrm{CDCl}_{3}\right): \delta 1.26-1.37(6 \mathrm{H}$, m); $2.19(3 \mathrm{H}, \mathrm{s}) ; 2.76(1 \mathrm{H}, \mathrm{d} x \mathrm{~d}, \mathrm{~J}=13.0,5.4 \mathrm{~Hz}) ; 3.22(1 \mathrm{H}, \mathrm{d}$ x d, J=13.0, 9.8Hz); $3.79(1 \mathrm{H}$, q, J=6.8Hz); 4.19-4.30 (3H, m); 7.22-7.35 (5H, m). $\left.{ }^{13} \mathrm{C} \mathrm{NMR} \mathrm{(50} \mathrm{MHz,} \mathrm{CDCl}_{3}\right): \delta 14.0,16.3$, 38.4, 54.1, 58.1, 61.8, 63.1, 127.0, 127.6, 128.1, 142.4, 169.4. HRMS (ESI) calcd for $\mathrm{C}_{14} \mathrm{H}_{20} \mathrm{ClNO}_{2} \mathrm{Na}(\mathrm{M}+\mathrm{Na})^{+} 292.1080$, found 292.1084.

\section{Acknowledgements}

The authors are indebted to the "Fund for Scientific Research - Flanders (Belgium)" (FWOVlaanderen), Ghent University (GOA), the Korea Science and Engineering Foundation (R012007-000-20037-0) and the Center for Bioactive Molecular Hybrides for financial support. Computational resources and services used in this work were provided by Ghent University. 
Supporting Information: Cartesian coordinates, imaginary and low frequency modes (B3LYP/6-31++G** optimized) for solvent assisted ring opening transition states, and single point energy from MPW1B95/6-31++G** calculations (Tables S1- S6).

\section{References}

[1] (a) U. M. Lindström, P. Somfai, Synthesis 1998, 1998, 109-117. (b) B. Zwanenburg, P. ten Holte, Top. Curr. Chem. 2001, 216, 93-124. (c) J. B. Sweeney, Chem. Soc. Rev. 2002, 31, 247-258. (d) X. E. Hu, Tetrahedron 2004, 60, 2701-2743. (e) D. Tanner, Angew. Chem. Int. Ed. 1994, 33, 599-619. (f) H. M. I. Osborn, J. Sweeney, Tetrahedron: Asymmetry 1997, 8, 1693-1715. (g) W. M. McCoull, F. A. Davis, Synthesis 2000, 1347-1365. (h) I. D. G. Watson, L. Yu, A. K. Yudin, Acc. Chem. Res. 2006, 39, 194-206. (i) A. Padwa, S. S. Murphree, Arkivoc 2006, (iii), 6-33. (j) Tsang, D. S.; Yang, S.; Alphonse, F. A.; Yudin, A. K. Chem. Eur. J. 2008, 14, 886-894. (k) G. S. Singh, M. D’hooghe, N. De Kimpe, Chem. Rev. 2007, 107, 2080-2135.

[2] (a)Y.-Q. Fang, R. Karisch, M. Lautens, J. Org. Chem. 2007, 72, 1341-1346. (b) F. Couty, O. David, B. Larmanjat, J. Marrot, J. Org. Chem. 2007, 72, 1058-1061. (c) B. C. H. May, J. A. Zorn, J. Witkop, J. Sherrill, A. C. Wallace, G. Legname, S. B. Prusiner, F. E. Cohen, J. Med. Chem. 2006, 50, 65-73. (d) M. D’hooghe, N. De Kimpe, Tetrahedron 2008, 64, 32753285 .

[3] (a) S. J. Whittaker, F. M. Foss, Cancer Treat. Rev. 2007, 33, 146-160. (b) W. A. Denny, Curr. Med. Chem. 2001, 8, 533-544.

[4] (a) J. L. Pierre, P. Baret, E. M. Rivoirard, J. Heterocyclic Chem. 1978, 15, 817-823. (b) A. R. Bassindale, P. A. Kyle, M. C. Soobramanien, P. G. Taylor, J. Chem. Soc., Perkin Trans. 1 2000, 439-448. (c) K. Weber, S. Kuklinski, P. Gmeiner, Org. Lett. 2000, 2, 647-649. (d) D. Gnecco, L. Orea F., A. Galindo, R. G. Enríquez, R. A. Toscano, W. F. Reynolds, Molecules, 2000, 5, 998-1003. (e) B. Crousse, S. Narizuka, D. Bonnet-Delpon, J.-P. Begue, Synlett 2001, 679-681. (f) L. Testa, M. Akssira, E. Zaballos-García, P. Arroyo, L. R. Domingo, J. Sepúlveda-Arques, Tetrahedron, 2003, 59, 677-683. (g) T. N. Wade, J. Org. Chem. 1980, 45, 5328-5333. (h) G. M. Alvernhe, C. M. Ennakoua, S. M. Lacombe, A. J. Laurent, J. Org. Chem. 1981, 46, 4938-4948. (i) P. O’Brien, T. D. Towers, J. Org. Chem. 2002, 67, 304-307. 
(j) T. Katagiri, M. Takahashi, Y. Fujiwara, H. Ihara, K. Uneyama, J. Org. Chem. 1999, 64, 7323-7329. (k) K. Higashiyama, M. Matsumura, K. Hiroshi, T. Yamauchi, Heterocycles 2009, 78, 471-485. (1) H. A. Song, M. Dadwal, Y. Lee, E. Mick, H.-S. Chong, Angew. Chem. Int. Ed. 2009, 48, 1328-1330. (m) M. Kumar, S. K. Pandey, S. Gandhi, V. K. Singh, Tetrahedron Lett. 2009, 50, 363-365. (n) H.-S. Chong, H. A. Song, M. Dadwal, X. Sun, I. Sin, Y. Chen, J. Org. Chem. 2010, 75, 219-221. (o) T.-X. Métro, B. Duthion, D. Gomez Pardo, J. Cossy, Chem. Soc. Rev. 2010, 39, 89-102.

[5] (a) T. B. Sim, S. H. Kang, K. S. Lee, W. K. Lee, H. Yun, Y. Dong, H.-J. Ha, J. Org. Chem., 2003, 68, 104-108. (b) M. D'hooghe, V. Van Speybroeck, M. Waroquier, N. De Kimpe, Chem. Commun. 2006, 1554-1556. (c) M. D’hooghe, N. De Kimpe, Synlett 2006, 2089-2093. (d) M. D'hooghe, V. Van Speybroeck, A. Van Nieuwenhove, M. Waroquier, N. De Kimpe, J. Org. Chem. 2007, 72, 4733-4740. (e) M. D’hooghe, K. Vervisch, A. Van Nieuwenhove, N. De Kimpe, Tetrahedron Lett. 2007, 48, 1771-1774. (f) M. D'hooghe, K. Vervisch, N. De Kimpe, J. Org. Chem. 2007, 72, 7329-7332. (g) Y. Kim, H.-J. Ha, S. Y. Yun, W. K. Lee, Chem. Commun. 2008, 4363-4365. (h) S. Y. Yun, S. Catak, W. K. Lee, M. D’hooghe, N. De Kimpe, V. Van Speybroeck, M. Waroquier, Y. Kim, H.-J. Ha, Chem. Commun. 2009, 2508-2510. (i) S. Catak, M. D’hooghe, N. De Kimpe, M. Waroquier, V. Van Speybroeck, J. Org. Chem. 2010, 75, 885-896.

[6] (a) N. De Kimpe, R. Jolie, D. De Smaele, J. Chem. Soc., Chem. Commun. 1994, 12211222. (b) N. De Kimpe, D. De Smaele, Z. Szakonyi, J. Org. Chem. 1997, 62, 2448-2452. (c) M. D'hooghe, A. Waterinckx, N. De Kimpe, J. Org. Chem. 2004, 70, 227-232.

[7] M. D’hooghe, A. Waterinckx, T. Vanlangendonck, N. De Kimpe, Tetrahedron 2006, 62, 2295-2303.

[8] M. Sivaprakasham, F. Couty, G. Evano, B. Srinivas, R. Sridhar, K. Rama Rao, Arkivoc 2007, $(x), 71-93$.

[9] C. Lee, W. Yang and R. G. Parr, Phys. Rev. B 1988, 37, 785-789.

[10] A. D. Becke, J. Chem. Phys. 1993, 98, 5648-5652.

[11] K. Fukui, Acc. Chem. Res. 2002, 14, 363-368.

[12] Y. Zhao and D. G. Truhlar, J. Phys. Chem. A 2004, 108, 6908-6918.

[13] M. Gerenkamp and S. Grimme, Chem. Phys. Lett. 2004, 392, 229-235.

[14] Tomasi, J.; Mennucci, B.; Cammi, R. Chem. Rev. 2005, 105, 2999-3094.

[15] (a) Barone, V.; Cossi, M. J. Phys. Chem. A 1998, 102, 1995-2001. (b) Cossi, M.; Rega, N.; Scalmani, G.; Barone, V. J. Comp. Chem. 2003, 24, 669-681. 
[16] M. J. T. Frisch, G. W.; Schlegel, H. B.; Scuseria, G. E.; Robb, M. A.; Cheeseman, J. R.; Montgomery, Jr., J. A.; Vreven, T.; Kudin, K. N.; Burant, J. C.; Millam, J. M.; Iyengar, S. S.; Tomasi, J.; Barone, V.; Mennucci, B.; Cossi, M.; Scalmani, G.; Rega, N.; Petersson, G. A.; Nakatsuji, H.; Hada, M.; Ehara, M.; Toyota, K.; Fukuda, R.; Hasegawa, J.; Ishida, M.; Nakajima, T.; Honda, Y.; Kitao, O.; Nakai, H.; Klene, M.; Li, X.; Knox, J. E.; Hratchian, H. P.; Cross, J. B.; Bakken, V.; Adamo, C.; Jaramillo, J.; Gomperts, R.; Stratmann, R. E.; Yazyev, O.; Austin, A. J.; Cammi, R.; Pomelli, C.; Ochterski, J. W.; Ayala, P. Y.; Morokuma, K.; Voth, G. A.; Salvador, P.; Dannenberg, J. J.; Zakrzewski, V. G.; Dapprich, S.; Daniels, A. D.; Strain, M. C.; Farkas, O.; Malick, D. K.; Rabuck, A. D.; Raghavachari, K.; Foresman, J. B.; Ortiz, J. V.; Cui, Q.; Baboul, A. G.; Clifford, S.; Cioslowski, J.; Stefanov, B. B.; Liu, G.; Liashenko, A.; Piskorz, P.; Komaromi, I.; Martin, R. L.; Fox, D. J.; Keith, T.; Al-Laham, M. A.; Peng, C. Y.; Nanayakkara, A.; Challacombe, M.; Gill, P. M. W.; Johnson, B.; Chen, W.; Wong, M. W.; Gonzalez, C.; and Pople, J. A. in Gaussian 03 Vol. Gaussian, Inc., Wallingford CT, 2004.

[17] (a) S. Catak, G. Monard, V. Aviyente, M. F. Ruiz-Lopez, J. Phys. Chem. A 2006, 110, 8354-8365. (b) S. Catak, G. r. Monard, V. Aviyente, M. F. Ruiz-LoÌ??pez, J. Phys. Chem. A 2008, 112, 8752-8761. (c) S. Catak, G. r. Monard, V. Aviyente, M. F. Ruiz-LoÌpez, J. Phys. Chem. A 2009, 113, 1111-1120. (d) V. Van Speybroeck, K. Moonen, K. Hemelsoet, C. V. Stevens, M. Waroquier, J. Am. Chem. Soc. 2006, 128, 8468-8478. (e) B. De Sterck, R. Vaneerdeweg, F. Du Prez, M. Waroquier, V. Van Speybroeck, Macromolecules 2009, in press.

[18] (a) C. J. Cramer, D. G. Truhlar in Continuum Solvation Models, Vol. Kluwer, Dordrecht, 1996, pp. 1-80. (b) J. Tomasi, B. Mennucci, R. Cammi, Chem. Rev. 2005, 105, 2999-3094.

[19] (a) E. F. da Silva, H. F. Svendsen, K. M. Merz, J. Phys. Chem. A 2009, 113, 6404-6409. (b) C. P. Kelly, C. J. Cramer, D. G. Truhlar, J. Phys. Chem. A 2006, 110, 2493-2499. (c) J. R. Pliego, J. M. Riveros, J. Phys. Chem. A 2001, 105, 7241-7247.

[20] S. C. L. Kamerlin, M. Haranczyk, A. Warshel, ChemPhysChem 2009, 10, 1125-1134.

[21] (a) A. P. Bento and F. M. Bickelhaupt, J. Org. Chem. 2008, 73, 7290-7299. (b) Bickelhaupt, F. M. J. Computational Chem. 1999, 20, 114-128.

[22] (a) D. H. Ess and K. N. Houk, J. Am. Chem. Soc. 2008, 130, 10187-10198. (b) Ess, D. H.; Houk, K. N. J. Am. Chem. Soc. 2007, 129, 10646-10647.

[23] Jong, G. T. d.; Bickelhaupt, F. M. ChemPhysChem 2007, 8, 1170-1181. 